\title{
Chemical and Statistical Studies on Water and Stream Sediments Around the Coal Mine Area in Dazhu, China
}

\section{Dongping Deng}

Chengdu University of Technology

\section{Yong Wu ( $\nabla$ ywu@cdut.edu.cn )}

State key laboratory for Geohazard Prevention and Geoenvironment Protection, Chengdu University of

Technology

\section{Bangzheng Ren}

Chengdu University of Technology

\section{Heng Yin}

Chengdu University of Technology

\section{Research Article}

Keywords: Water, Stream sediment, Hydrochemistry, Geochemistry, Statistical analysis

Posted Date: April 27th, 2021

DOl: https://doi.org/10.21203/rs.3.rs-452252/v1

License: (c) (i) This work is licensed under a Creative Commons Attribution 4.0 International License. Read Full License 


\title{
Chemical and statistical studies on water and stream sediments around the coal mine area in Dazhu, China
}

\author{
Dongping Deng ${ }^{\mathrm{a}, \mathrm{b}}$, Yong $\mathrm{Wu}^{\mathrm{a}, \mathrm{b},{ }^{*}}$, Bangzheng Ren ${ }^{\mathrm{a}, \mathrm{b}}$, Heng Yin ${ }^{\mathrm{a}, \mathrm{b}, \mathrm{c}}$ \\ ${ }^{a}$ College of Environment and Civil Engineering, Chengdu University of Technology, \\ Chengdu 610059, China \\ ${ }^{\mathrm{b}}$ State Key Laboratory of Geohazard Prevention and Geoenvironment Protection, Chengdu \\ 610059, China \\ ${ }^{\mathrm{c}}$ Sichuan Academy of Safety Science and Technology, Chengdu 610045, China \\ * Corresponding author. E-mail address: ywu@cdut.edu.cn (Yong Wu)
}

\begin{abstract}
Coal mine pollution has become one of the most serious environmental problems in China and elsewhere. Water, in the form of groundwater and streams, as well as stream sediment samples, were collected from the coal mine area in Dazhu, Southwestern China. Different analyses, including the hydro-geochemical, multivariate analyses and X-ray analyses, were conducted to examine the coal mine pollution effect. The study results show that the groundwater and stream samples are slightly acidic to alkaline with $\mathrm{pH}$ values of 6.36 to 7.17 and 6.51 to 7.39 , respectively. With the dissolution of carbonate and sulfate, a large amount of $\mathrm{Ca}^{2+}, \mathrm{Mg}^{2+}$, and $\mathrm{SO}_{4}{ }^{2-}$ is found in the groundwater and stream samples, which is higher than the environmental background value. Typically, the water samples are dominated by $\mathrm{Ca}^{2+}+\mathrm{Mg}^{2+}-\mathrm{HCO}_{3}{ }^{-}$and $\mathrm{Ca}^{2+}+\mathrm{Mg}^{2+}-\mathrm{Cl}^{-}$. According to Chinese standard and the World Health Organization's guidelines, the water in the coal mine area is of good quality in terms of its physical and chemical properties, except for the concentrations of Fe and $\mathrm{Mn}$ (1925.14 and $12872.882 \mu \mathrm{g} / \mathrm{L}$, respectively). Principal component analysis reveal two groups that explained the variance in the data consisting of $\mathrm{SO}_{4}{ }^{2-}, \mathrm{Ca}^{2+}, \mathrm{Mg}^{2+}$, and low $\mathrm{pH}$ as well as $\mathrm{HCO}_{3}{ }^{-}, \mathrm{Na}^{+}$, and $\mathrm{Cl}^{-}$, which can reflect the acid mine drainage effects as well as different human activities or the evaporation found in low mountains and hills, respectively. Hence, the concentrations of metals and metalloids in the stream sediments are affected by the coal mine drainage, which are generally enriched in $\mathrm{Cr}, \mathrm{Mn}, \mathrm{Zn}, \mathrm{Sr}, \mathrm{Co}, \mathrm{Ni}, \mathrm{Cu}, \mathrm{Al}, \mathrm{Ca}, \mathrm{Fe}$, and $\mathrm{Mg}$. $\mathrm{Mn}$ and $\mathrm{Fe}$ average concentrations are higher in the downstream Kongjiagou drain stream sediment samples were $2035.03 \mathrm{ppm}$ and $6 \%$, respectively, relative to the $\mathrm{Mn}$ and $\mathrm{Fe}$ average concentrations in Xiaojiagou of $453.04 \mathrm{ppm}$ and $2.96 \%$, respectively. Both $\mathrm{Mn}$ and Fe concentrations are higher than the background values. Ultimately, mine closures can help with the process of ecological and environmental recovery. Key words: Water, Stream sediment, Hydrochemistry, Geochemistry, Statistical analysis.
\end{abstract}

\section{Introduction}

Chinese coal is one of the world's main sources of coal and accounts for approximately $76 \%$ of China's primary energy consumption, which is predicted to be China's primary energy source in the long-term (Du, 2011). In the 1990s, thousands of coal mines were operating in China, most of which were small-sized and distributed in the shallow areas of larger state-owned coal mines. By the end of 2016, the number of coal mines has plummeted to less than 8000 and more than 90,000 coal mines have been closed in the past 20 years (Wu and Li, 2018).

When mining, the coal drainage would be continuously drained on the road, in which oxygen would enter the underground environment and oxidize the pyrite in the coal, forming sulfate or even sulfuric acid after the oxidation. These reactions generate an acidic wastewater, which is usually referred to as the acid mine drainage (AMD) (Xu et al., 2007; Katrina et al., 1999). AMD would react with the carbonate and silicate minerals in the aquifer, which is often rich in sulfuric acid and heavy metals (McDonough et al., 2005; Zhang et al., 2015).

The distribution characteristics and the element sources in the coal and coal-bearing strata as well as their harm to the environment were examined, in which the results showed that the coal seams were easy to be enriched with toxic and harmful elements, such as $\mathrm{Pb}, \mathrm{As}, \mathrm{Cd}, \mathrm{Hg}, \mathrm{Cr}, \mathrm{Zn}$, Fe, Mn, S, Se, Sb, Tl, Be, F, and Cl (Zeng et al., 2005; Baioumy, 2005; Kissao and Heinz, 2003). Moreover, the AMD would pollute the groundwater in the other aquifers through the cracks generated from the coal mining (Lv et al.,2005; Zhou et al., 2006). With the discharge of AMD, these elements would pollute the surface water, the stream sediment, and the soil at the downstream 
of outfall (Khalil et al.,2013; Bhattacharya et al., 2012; Salomão et al., 2020), which can gravely affect the quality of life and productivity of the residents in the mining area. Thus, studying the water and stream sediments from coal mine drainage can support water resource management, water quality evaluation as well as water and stream sediment restoration.

In this work, the main objectives were to (1) analyze the physicochemical and chemical properties of the groundwater and stream flowing downstream from the coal mine drainage; (2) to assess the water and stream sediment quality based on the guidelines provided by Chinese standard and the World Health Organization (WHO, 2011); (3) to statistically analyze the correlations between the ions in the samples and determine the main contributing factors; and (4) to identify the correlation between the coal mine drainage and the stream sediments that affect the release and migration of pollutants into the study area.

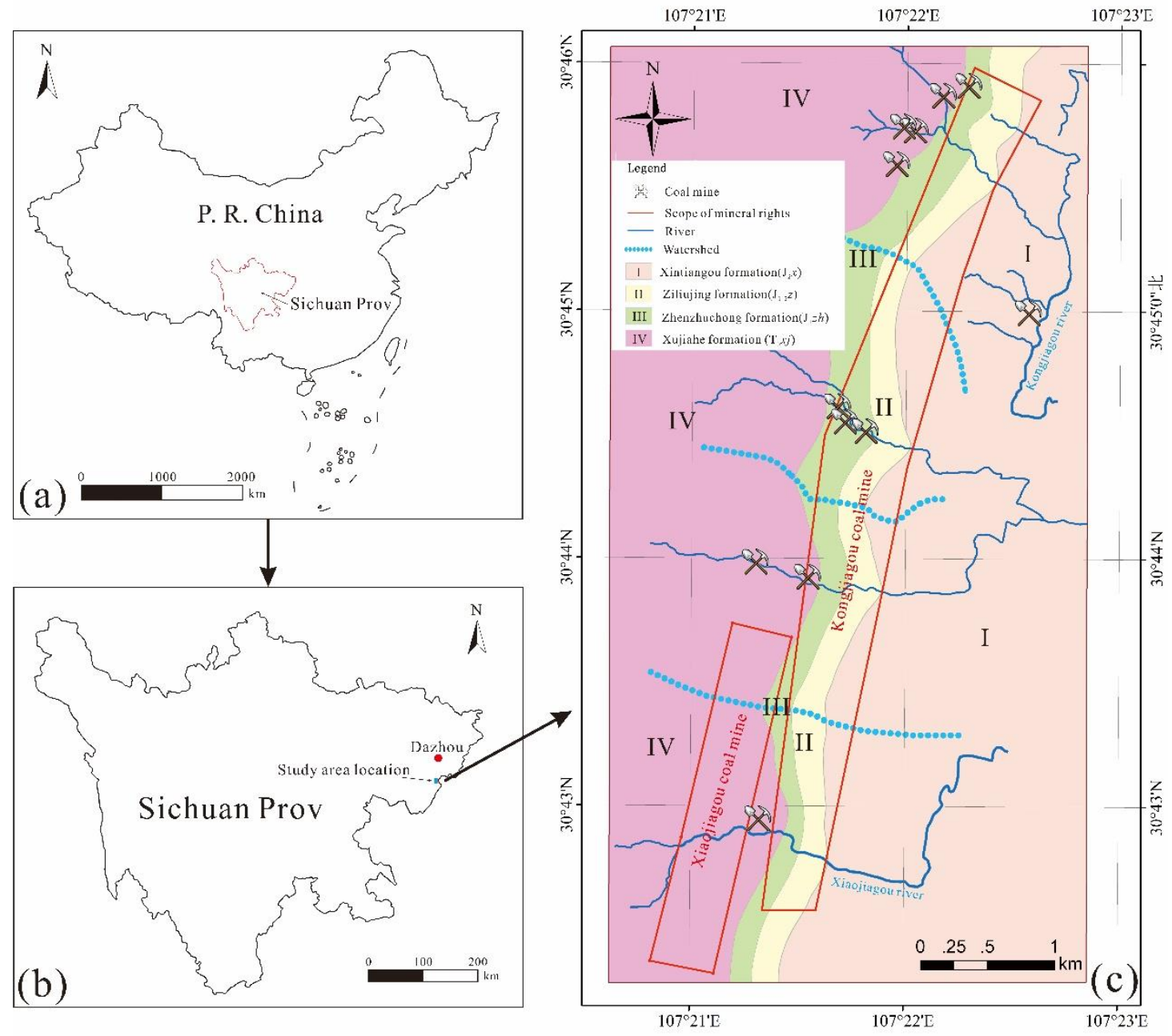

Fig. 1. (a) the Sichuan Province in China, (b) location of study area in Sichuan Province, (c) geological and hydrogeological map of study area.

\section{The study area}

This work was conducted approximately $15 \mathrm{~km}$ northeast of Dazhu County, Dazhou City, Southwest Sichuan Province, China, which is under the administration of the Xinsheng township of the Dazhu County (Fig.1) and in the East Sichuan fold belt of the Neocathaysian Sichuan subsidence belt. It is composed of a series of anticlines and synclines, where the anticline is narrow, long, and compact, while the syncline is open and gentle, arranged in an echelon, and its axial distribution is northeast-southwest. The natural watershed is composed of sandstone in the Xujiahe Triassic formation with high and low terrain to the west and east, respectively. Because it is divided by the east-west transverse valley, the formed "V" shaped valley is densely distributed in the whole area.

Furthermore, the study area has a subtropical monsoon climate zone with four distinct seasons. This included a warm-humid climate, heavy rainfall in the summer as well as rain and fog in the winter, with an average frost-free period of 347 days. The annual average temperature is $18^{\circ} \mathrm{C}$, with 
extreme temperature values -4.0 to $40.2{ }^{\circ} \mathrm{C}$. The average and extreme annual precipitation values are approximately $1245.7 \mathrm{~mm}$ and 840.9 to $1495.9 \mathrm{~mm}$, respectively, where the precipitation from May to September accounts for $60 \%$ of the entire year. Abundant annual precipitation would provide sufficient water supply for groundwater and stream formation.
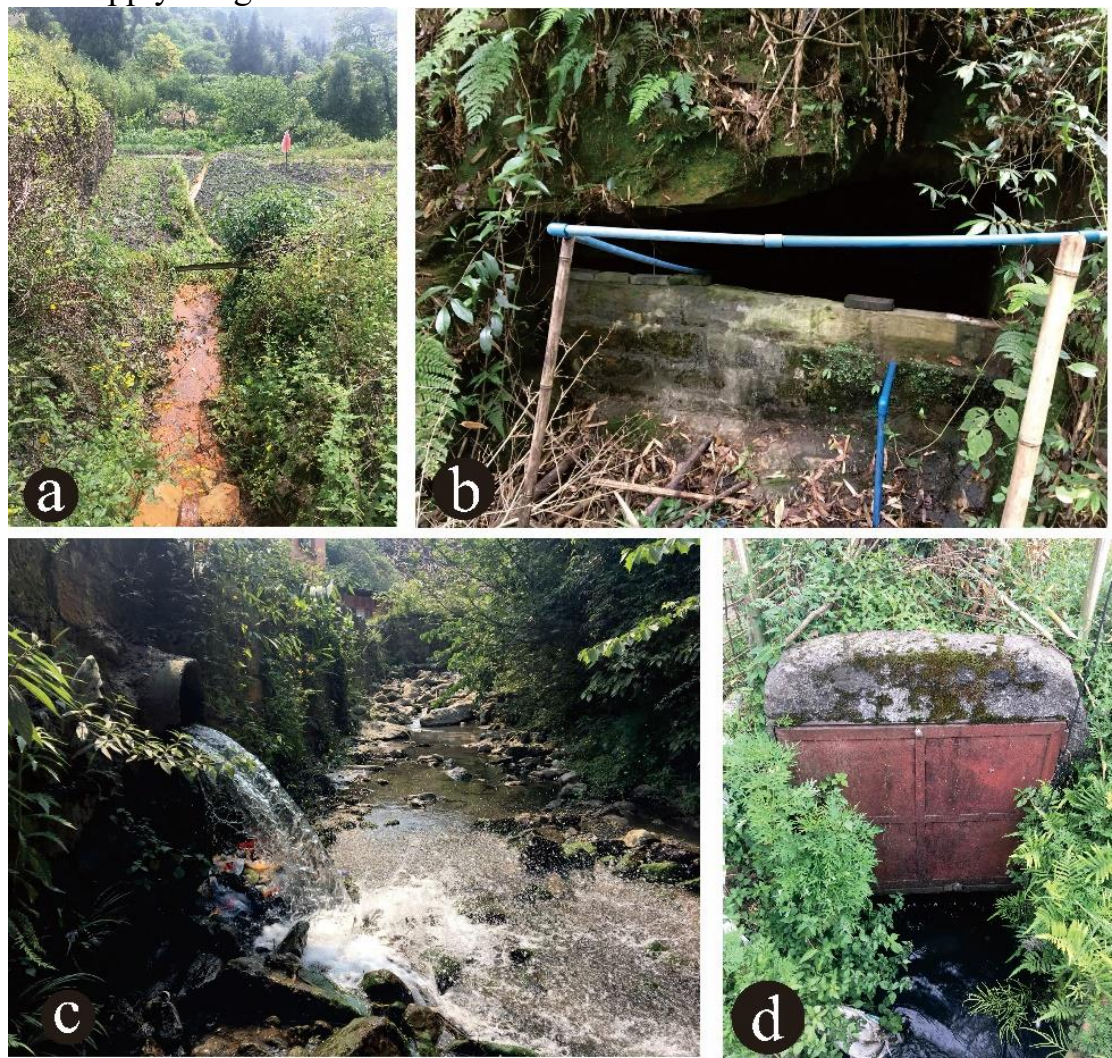

Fig.2. The study area: (a) coal mine drainage for agriculture, (b) pipes at the pithead, (c) drain of Xiaojiagou coal mine, (d) drain of Kongjiagou coal mine.

The exposed strata in the study area included the Xujiahe Triassic formation $\left(\mathrm{T}_{3} x j\right)$, the Zhenzhuchong Jurassic formation $\left(\mathrm{J}_{1} z h\right)$, the Ziliujing Jurassic formation $\left(\mathrm{J}_{1-2} z\right)$, and the Xintiangou Jurassic formation $\left(\mathrm{J}_{2} x\right)$ (Fig.1) (Jiang, 2016). Xujiahe formation is the coal bearing strata in the area, with a continental sedimentary environment that is composed of dark grey mudstone, shale, fine sandstone, siltstone, and coal seam ( $\mathrm{Li}, 2014)$. The Zhenzhuchong formation is mainly composed of grey, greenish grey mudstone, and silty mudstone, with a small amount of purplish red mudstone in the upper part, with several coal seams in the lower part and a small amount of chert gravel at the bottom. The type of groundwater in both the $\mathrm{T}_{3} x j$ and $\mathrm{J}_{1} z h$ was the clastic rock interlayer fissure water, where the water inflow of a single well was $100-500 \mathrm{t} / \mathrm{d}$ and the mineralization degree was less than $0.5 \mathrm{~g} / \mathrm{L}$. The Ziliujing formation is mainly composed of grey to dark grey mudstone with a thin layer of argillaceous siltstone and siltstone, which is rich in lamellibranchia fossils. The groundwater type was fissure karst water of suitable yield. The spring flow is $0.1-10 \mathrm{~L} / \mathrm{s}$, while the mineralization degree is $0.1-0.4 \mathrm{~g} / \mathrm{L}$. Finally, the Xintiangou formation is composed of mudstone, silty mudstone, and fine sandstone, where the sandstone is the aquifer and the mudstone is the relative aquifuge. The groundwater type was of red bed confined water, in which the depth of the water-bearing part was approximately 30 to $150 \mathrm{~m}$, while the water inflow of a single well is 100$500 \mathrm{t} / \mathrm{d}$, with a mineralization degree of less than $0.5 \mathrm{~g} / \mathrm{L}$ (Jiang, 2009).

Since the 1960s, more than ten coal mines operated in the chosen study area (Fig. 1). Except Kongjiagou coal mine, which is still mining, other coal mines have been closed between 1990 and 2010 due to pollution and the economic changes. Once the abandoned coal mine ceases the drainage, the mine's water level would gradually rise and stablize with the recharge of groundwater or surface water, forming a large water body (Hu et al.,2010). Finally, the coal mine drainage would flow out from the pithead as the mine water continues to fill. Local residents would connect pipes to the pithead to use as drinking or irrigation water (Fig. 2a and 2b).

All the coal mines in study area were underground mines, and the coal seam is located in Xujiahe formation. Mineral compositions such as quartz, feldspar, muscovite, pyrite and filling can 
be observed from the strata of Xujiahe formation (Li, 2014). Output of these coal mines was mainly bright coal, followed by dark coal. Bright coal shiny strong with a sandwich coal, dark coal, charcoal thin layer. Dark coal shiny light with a small amount lens line theory of specular coal and silk charcoal The average moisture content in the raw coal was less than $0.9 \%$, while the average yield of volatile matter ( $\mathrm{V}_{\text {daf }}$ ) was $29.04 \%$ to $33.36 \%$ and the $\mathrm{CO}_{2}$ content was less than $2 \%$. ( $\mathrm{Li}$ et al., 2018).

\section{Materials and methods}

\subsection{Data collection and sample analysis}

Mine drainage was found at the pithead of seven abandoned mines in the study area, so seven groundwater samples (P1-P5, P7, P8) were collected from the pithead, The Xiaojiagou coal mine and Kongjiagou coal mine were discharging coal mine drainage downstream (Fig. 2d and 2e). Therefore, eight stream water samples (P6, P9-P15) and seven stream sediment samples (S1-S7) were collected $0,100,500$, and $1000 \mathrm{~m}$ away from the mine drain. All samples were collected in April 2020 (dry season) and October 2020 (wet season) with their locations shown in Fig. 3 using the Global Positioning System (GPS) to record the locations of the samples. The groundwater was collected 1-2 m below the well, while the stream samples were collected $20 \mathrm{~cm}$ below the surface of the water. Each sample was collected in two sealed high-density polyethylene bottles, where one bottle was acidified with nitric acid for testing the cations and trace elements. All samples were stored at $5{ }^{\circ} \mathrm{C}$ and immediately shipped to the lab for further analysis.

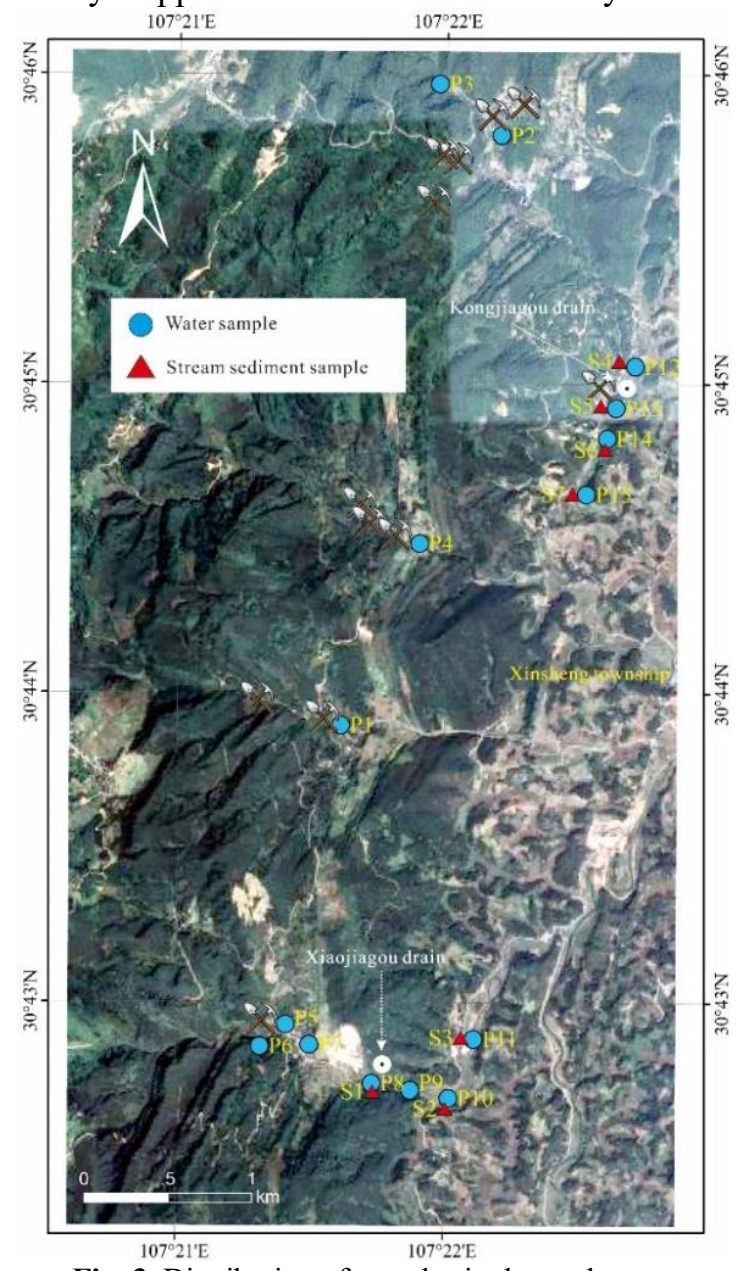

Fig. 3. Distribution of samples in the study area.

The physicochemical parameters, such as $\mathrm{pH}$, Eh, dissolved oxygen (DO), electrical conductivity (EC), and total dissolved solids (TDS) were measured in the field, using a watermonitoring instrument (Aquaread AP-800, UK). Major anions $\left(\mathrm{Cl}^{-}, \mathrm{SO}_{4}{ }^{2-}\right)$ were measured using ion chromatography with a 761 Compact IC Model (Metrohm AG, Switzerland), while the major cations $\left(\mathrm{K}^{+}, \mathrm{Na}^{2+}, \mathrm{Ca}^{2+}\right.$, and $\left.\mathrm{Mg}^{2+}\right)$ were analyzed using the inductively coupled plasma atomic emission spectrometry (ICP-AES) (iCAP 7400, Thermo Fisher Scientific, USA), while the trace 
elements of Li, B, Al, Ti, Mn, Fe, Ni, Zn, Mo and Ba were analyzed using ICP-MS (Agilent 7700, Agilent Scientific Instruments, USA).

The stream sediment samples were collected downstream of mine drainage outlet at a depth of 10-20 cm (Fig. 3) and packed in black polyethylene bags that were transported to the laboratory. After being air-dried, each sample was ground to $<74 \mu \mathrm{m}$ for the chemical analysis. The ICP-MS and $\mathrm{AES}$ were deployed to determine the concentrations of 20 elements, including major oxides and trace elements, such as $\mathrm{Fe}_{2} \mathrm{O}_{3}, \mathrm{Al}_{2} \mathrm{O}_{3}, \mathrm{Mn}, \mathrm{Cr}, \mathrm{Cu}, \mathrm{Pb}$, and $\mathrm{Zn}$. All tests were conducted in the Chengdu Comprehensive Rock and Mineral Testing Center of the Sichuan Provincial Bureau of Geology and Mineral Exploration and Development. The ionic balance in all the analytical data were found to be within a limit of less than $( \pm 5 \%)$. To estimate the pollution level of the groundwater and the stream sediment of the study area, the guidelines for drinking water quality (WHO, 2011) and the Chinese standards for water and soil contamination were adhered and referred to in the study.

The mineralogical characterization of samples (S1 and S4) was carried out by X-ray diffraction (XRD) using a Rigaku diffractometer (Ultima IV). The conditions were slit fixed at $10 \mathrm{~mm}$, $0.5 \mathrm{mmPb}$ monochromatic radiation, $40 \mathrm{~mA}$ and $40 \mathrm{kV}$. Samples were run at a speed of $30^{\circ} / \mathrm{min}(20-$ $\left.70^{\circ}\right)$.

\subsection{Statistical analysis}

In the field of environmental science, the multivariate analysis has become a more powerful tool than the classical single variable method as it makes data analysis easier (Hou et al., 2017). Multivariate analysis methods, such as principal component analysis (PCA) and factor analysis (FA) have been successfully applied to assess the quality of the water and the stream sediment to identify the chemical processes therein (Qin et al., 2019; Narváez et al., 2007; Mostert et al., 2010; Atulya et al., 2017; Lu et al., 2016).

In order to characterize and compare these parameters, the SPSS Statistics v22 software (International Business Machines Corporation, USA) was used to analyze the chemical properties of the water and stream sediment samples. PCA was applied to the water quality variable analysis (Amari, 2014), while FA quickly simplified the data by extracting the eigenvalues and eigenvectors from the correlation coefficient matrix (Davis and Sampson, 1986). The Kaiser-Meyer-Olkin (KMO) and Bartlett's tests of sphericity have been frequently used to test the appropriateness of FA with the data. In our study, the sphericity (0.6) was larger than 0.5 and the KMO result was less than $<0.001$ level, indicating that the data was suitable for FA. In total, eight parameters of $\mathrm{pH}, \mathrm{EC}, \mathrm{HCO}_{3}^{-}, \mathrm{SO}_{4}^{2-}$, $\mathrm{Cl}, \mathrm{Na}, \mathrm{Ca}$, and $\mathrm{Mg}$ were measured in the water samples, while 15 parameters of $\mathrm{Cr}, \mathrm{Mn}, \mathrm{Co}, \mathrm{Ni}$, $\mathrm{Cu}, \mathrm{Zn}, \mathrm{Rb}, \mathrm{Sr}, \mathrm{Pb}, \mathrm{P}, \mathrm{Ti}, \mathrm{Al}_{2} \mathrm{O}_{3}, \mathrm{CaO}, \mathrm{Fe}_{2} \mathrm{O}_{3}$, and $\mathrm{MgO}$ were measured in the stream sediment samples that were used in the statistical analysis of the data.

\section{Results and discussion}

\subsection{Water samples}

\subsubsection{Hydrochemical characteristics}

The physicochemical and chemical properties of the water samples from the study area have been summarized in Table 1 and 2, where the water samples (P6 and P12) were collected upstream of the Xiaojiagou and Kongjiagou coal mine drainage to represent the two background values, respectively. The temperature difference between the groundwater and the stream was approximately $10^{\circ} \mathrm{C}$, which could have been affected by the temperature exceeding $22^{\circ} \mathrm{C}$ during the collection. In dry season, groundwater and stream samples were slightly acidic to alkaline with $\mathrm{pH}$ values of 6.63 to 7.17 and 6.51 to 7.39 , respectively. Compere with dry season, the $\mathrm{pH}$ values of groundwater were slightly acidic to alkaline from 6.36 to 7.1 and stream samples were acidic from 6.51 to 6.95 in wet season. The $\mathrm{pH}$ of P6 in the dry season from upstream water sample point of the Xiaojiagou drainage drain was weakly alkaline, while the $\mathrm{pH}$ of the downstream water samples was weakly acidic, indicating that a large amount of weakly acidic mine water was discharged after the Xiaojiagou coal mine was abandoned and leading to the decrease in $\mathrm{pH}$. Most stream samples had EC values higher than the groundwater samples both in dry and wet season. The groundwater seemed to be more pure and contained less dissolved solids. Moreover, the groundwater and stream samples were oxidized, except for two samples (P2 and P4), which had a negative Eh value, where more oxygen was found in the in stream samples relative to the groundwater samples. 
Physico-chemical and chemical results of water samples in the study area (dry season).

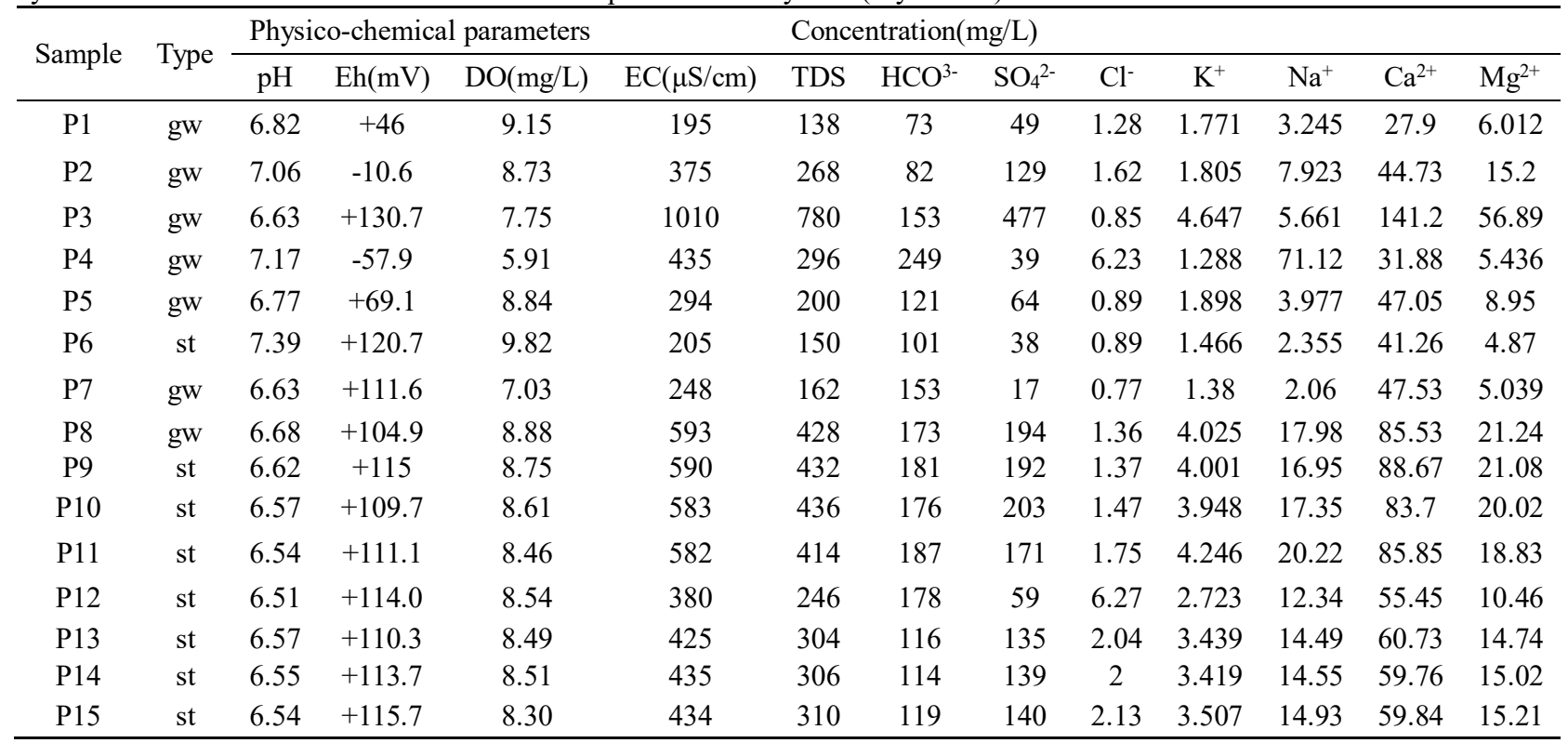

Eh—relative to field pH electrode; DO—dissolved oxygen; EC—electrical conductivity; TDS — total dissolved solids; gw—groundwater; st—stream.

Table 2

Physico-chemical and chemical results of water samples in the study area (wet season).

\begin{tabular}{|c|c|c|c|c|c|c|c|c|c|c|c|c|c|}
\hline \multirow{2}{*}{ Sample } & \multirow{2}{*}{ Type } & \multicolumn{4}{|c|}{ Physico-chemical parameters } & \multicolumn{8}{|c|}{ Concentration $(\mathrm{mg} / \mathrm{L})$} \\
\hline & & $\mathrm{pH}$ & $\mathrm{Eh}(\mathrm{mV})$ & $\mathrm{DO}(\mathrm{mg} / \mathrm{L})$ & $\mathrm{EC}(\mu \mathrm{S} / \mathrm{cm})$ & TDS & $\mathrm{HCO}_{3}{ }^{-}$ & $\mathrm{SO}_{4}^{2-}$ & $\mathrm{Cl}^{-}$ & $\mathrm{K}^{+}$ & $\mathrm{Na}^{+}$ & $\mathrm{Ca}^{2+}$ & $\mathrm{Mg}^{2+}$ \\
\hline P1 & gw & 6.6 & +128.5 & 8.96 & 52 & 35 & 51.9 & 19.1 & 1.4 & 2.565 & 4.483 & 21.06 & 3.406 \\
\hline $\mathrm{P} 2$ & gw & 7.1 & +35.8 & 8.63 & 341 & 222 & 72.3 & 129 & 1.49 & 3.077 & 11.11 & 55.29 & 17.7 \\
\hline P3 & gw & 6.36 & +208.6 & 7.79 & 685 & 445 & 111 & 318 & 0.614 & 5.404 & 7.117 & 118.5 & 48.54 \\
\hline P4 & gw & 6.48 & +146.5 & 8.86 & 115 & 74 & 241 & 15.4 & 6.73 & 2.101 & 89.53 & 24.37 & 2.431 \\
\hline P5 & gw & 6.97 & +35.6 & 8.99 & 146 & 94 & 119 & 23.2 & 0.885 & 2.303 & 4.051 & 45.09 & 5.319 \\
\hline P6 & st & 6.83 & +74.4 & 9.74 & 129 & 84 & 115 & 22.1 & 0.886 & 2.173 & 3.713 & 42.68 & 4.776 \\
\hline P7 & gw & 6.66 & +115.1 & 8.98 & 232 & 150 & 167 & 16.5 & 1.07 & 2.341 & 3.593 & 61.7 & 5.538 \\
\hline P8 & gw & 6.74 & +123.8 & 8.59 & 505 & 328 & 185 & 157 & 1.07 & 4.871 & 15.46 & 99.35 & 24.06 \\
\hline P9 & st & 6.85 & +81.6 & 9.03 & 469 & 302 & 187 & 144 & 1.21 & 4.683 & 14.09 & 96.24 & 21.88 \\
\hline P10 & st & 6.76 & +99.6 & 9.09 & 463 & 300 & 187 & 142 & 1.17 & 4.631 & 13.98 & 96.69 & 21.66 \\
\hline P11 & st & 6.95 & +54.4 & 8.19 & 458 & 297 & 189 & 166 & 1.48 & 5.671 & 31.11 & 94.96 & 21.6 \\
\hline P12 & st & 6.57 & +134.3 & 8.57 & 382 & 248 & 100 & 128 & 1.4 & 4.78 & 18.97 & 61.13 & 15.54 \\
\hline P13 & st & 6.66 & +107.6 & 8.57 & 390 & 254 & 128 & 106 & 3.07 & 4.996 & 20.35 & 66.46 & 15.17 \\
\hline P14 & st & 6.68 & +100.1 & 8.81 & 396 & 257 & 120 & 122 & 2.23 & 4.973 & 22.17 & 63.9 & 15.55 \\
\hline P15 & st & 6.51 & +125 & 8.25 & 311 & 202 & 122 & 120 & 2.27 & 4.909 & 22.21 & 64.35 & 14.91 \\
\hline
\end{tabular}

Eh—relative to field pH electrode; DO—dissolved oxygen; EC—electrical conductivity; TDS — total dissolved solids; gw—groundwater; st—stream.

To identify the sources and process the results of the mineralization of the water, plots of $\mathrm{Ca}^{2+}$ and $\mathrm{Mg}^{2+}$ relative to $\mathrm{SO}_{4}{ }^{2-}$ and $\mathrm{HCO}_{3}{ }^{-}$in dry and wet season were generated (Fig. 4), which showed that the correlations were suitable. This result can be explained by the complex influence of the dissolution and evaporation process of the gypsum or anhydrite. The excess $\mathrm{Ca}^{2+}$ and $\mathrm{Mg}^{2+}$ may be related to the dissolution of carbonate (Lghoul, et al., 2014). Furthermore, the Piper diagram (Piper, 1944) was used to analyze the main ions present in the water to highlight the relative concentrations of each ion in the water sample, which was divided into nine areas to show the differences of the geochemical characteristics and groundwater composition types in each area. Most of the groundwater and stream samples in dry and wet season were dominated by $\mathrm{Ca}^{2+}+\mathrm{Mg}^{2+}-\mathrm{HCO}_{3}{ }^{-}$and $\mathrm{Ca}^{2+}+\mathrm{Mg}^{2+}-\mathrm{Cl}^{-}$as shown in the Piper diagram (Fig. 5). However, the coal mine drainage samples $(\mathrm{P} 2$ and $\mathrm{P} 3)$ were dominated by $\mathrm{Ca}^{2+}+\mathrm{Mg}^{2+}-\mathrm{Cl}^{-}+\mathrm{SO}_{4}{ }^{2-}$, while the groundwater sample (P4) was dominated by $\mathrm{Ca}^{2+}+\mathrm{Na}^{+}-\mathrm{HCO}_{3}^{-}$. 
Table 3

Concentrations of trace elements of water samples from the study area.

\begin{tabular}{|c|c|c|c|c|c|c|c|c|c|c|c|c|c|c|c|c|c|c|}
\hline & $\begin{array}{c}\text { Element } \\
(\mu \mathrm{g} / \mathrm{L})\end{array}$ & $\mathrm{P} 1$ & P2 & $\mathrm{P} 3$ & P4 & P5 & P6 & P7 & P8 & P9 & P10 & P11 & $\mathrm{P} 12$ & P13 & P14 & P15 & $\mathrm{CNS}$ & WHO \\
\hline \multirow[t]{10}{*}{ Dry season } & $\mathrm{Li}$ & 9.09 & 16.976 & 117.192 & 8.486 & 9.315 & 3.106 & 4.008 & 35.903 & 27.009 & 29.313 & 27.114 & 6.438 & 24.657 & 13.793 & 22.834 & & \\
\hline & $\mathrm{B}$ & 26.294 & 51.599 & 162.972 & 120.307 & 46.542 & 27.728 & 25.394 & 187.508 & 161.069 & 182.298 & 183.053 & 53.775 & 125.28 & 124.037 & 120.66 & & \\
\hline & $\mathrm{Al}$ & 46.065 & 17.916 & 8.22 & 56.583 & 68.66 & 20.954 & 15.08 & 70.336 & 63.465 & 114.041 & 126.023 & 113.189 & 136.09 & 176.37 & 126.888 & 200 & 200 \\
\hline & $\mathrm{Ti}$ & 2.21 & 0.239 & 0.566 & 0.829 & 1.459 & 0.656 & 0.104 & 0.433 & 1.099 & 3.716 & 1.906 & 29.938 & 2.818 & 3.157 & 2.426 & & \\
\hline & $\mathrm{Mn}$ & 353.382 & 1925.136 & 36.487 & 132.878 & 100.857 & 5.672 & 16.741 & 108.039 & 70.767 & 54.537 & 35.032 & 29.816 & 11.456 & 14.99 & 19.679 & 100 & 100 \\
\hline & $\mathrm{Fe}$ & 1563.719 & 8356.48 & 44.578 & 260.374 & 1112.564 & 59.646 & 396.189 & 284.876 & 271.796 & 366.174 & 231.077 & 164.868 & 366.404 & 360.289 & 279.871 & 300 & 300 \\
\hline & $\mathrm{Ni}$ & 7.092 & 5.881 & 6.118 & 0.298 & 0.835 & 0.334 & 3.326 & 4.613 & 3.866 & 3.197 & 2.001 & 0.708 & 9.255 & 9.806 & 10.353 & 20 & 70 \\
\hline & $\mathrm{Zn}$ & 22.219 & 14.349 & 15.652 & 6.491 & 11.317 & 9.337 & 24.165 & 11.766 & 8.521 & 8.796 & 8.448 & 9.01 & 24.634 & 26.591 & 21.994 & 1000 & 3000 \\
\hline & Mo & 0.445 & 0.13 & 0.396 & 0.421 & 0.642 & 0.252 & 0.337 & 3.061 & 3.15 & 2.772 & 2.25 & 0.556 & 0.713 & 0.743 & 0.729 & & \\
\hline & $\mathrm{Ba}$ & 57.362 & 33.351 & 25.723 & 158.334 & 53.697 & 36.581 & 46.005 & 84.455 & 82.84 & 85.662 & 88.199 & 66.809 & 45.375 & 47.355 & 49.17 & 700 & 700 \\
\hline \multirow[t]{10}{*}{ Wet season } & $\mathrm{Li}$ & 3.862 & 13.712 & 98.214 & 1.759 & 2.074 & 1.677 & 2.204 & 23.864 & 19.491 & 19.037 & 31.221 & 20.584 & 15.398 & 18.714 & 15.918 & & \\
\hline & B & 20.982 & 34.871 & 96.494 & 71.061 & 14.201 & 11.691 & 11.239 & 107.758 & 105.696 & 92.531 & 137.632 & 101.594 & 90.571 & 108.886 & 103.342 & & \\
\hline & $\mathrm{Al}$ & 37.792 & 35.001 & 26.045 & 46.105 & 19.293 & 22.532 & 41.567 & 29.892 & 47.231 & 98.53 & 166.057 & 30.849 & 65.285 & 55.028 & 71.313 & 200 & 200 \\
\hline & $\mathrm{Ti}$ & 0.449 & 0.309 & 0.343 & 1.829 & 0.189 & 0.191 & 0.438 & 0.146 & 0.591 & 1.382 & 1.813 & 0.188 & 1.463 & 2.498 & 1.937 & & \\
\hline & $\mathrm{Mn}$ & 57.325 & 1883.86 & 72.802 & 136.577 & 21.516 & 5.298 & 10.887 & 15.566 & 10.281 & 17.435 & 69.496 & 1.701 & 15.078 & 14.386 & 17.462 & 100 & 100 \\
\hline & $\mathrm{Fe}$ & 228.754 & 12872.882 & 34.761 & 203.908 & 157.454 & 52.036 & 73.694 & 163.857 & 128.57 & 221.186 & 428.382 & 63.657 & 126.594 & 103.526 & 118.084 & 300 & 300 \\
\hline & $\mathrm{Ni}$ & 2.237 & 6.294 & 10.837 & 0.255 & 0.256 & 0.339 & 0.365 & 2.585 & 2.126 & 1.979 & 3.585 & 10.977 & 7.354 & 7.762 & 6.506 & 20 & 70 \\
\hline & $\mathrm{Zn}$ & 2.647 & 6.646 & 10.129 & 0.632 & 0.325 & 1.295 & 39.493 & 1.972 & 1.672 & 1.794 & 21.019 & 10.527 & 6.783 & 6.446 & 4.889 & 1000 & 3000 \\
\hline & Mo & 0.227 & 0.09 & 0.262 & 0.457 & 0.303 & 0.267 & 0.271 & 3.467 & 2.769 & 2.43 & 1.511 & 0.664 & 0.765 & 0.904 & 0.872 & & \\
\hline & $\mathrm{Ba}$ & 42.58 & 33.439 & 20.187 & 167.418 & 37.269 & 28.658 & 48.374 & 93.692 & 84.678 & 85.102 & 100.742 & 34.519 & 44.841 & 42.663 & 43.812 & 700 & 700 \\
\hline
\end{tabular}

CNS: China Standard (GB 5749-2006); WHO: World Health Organization (WHO, 2011).

More than standard value is given in bold. 

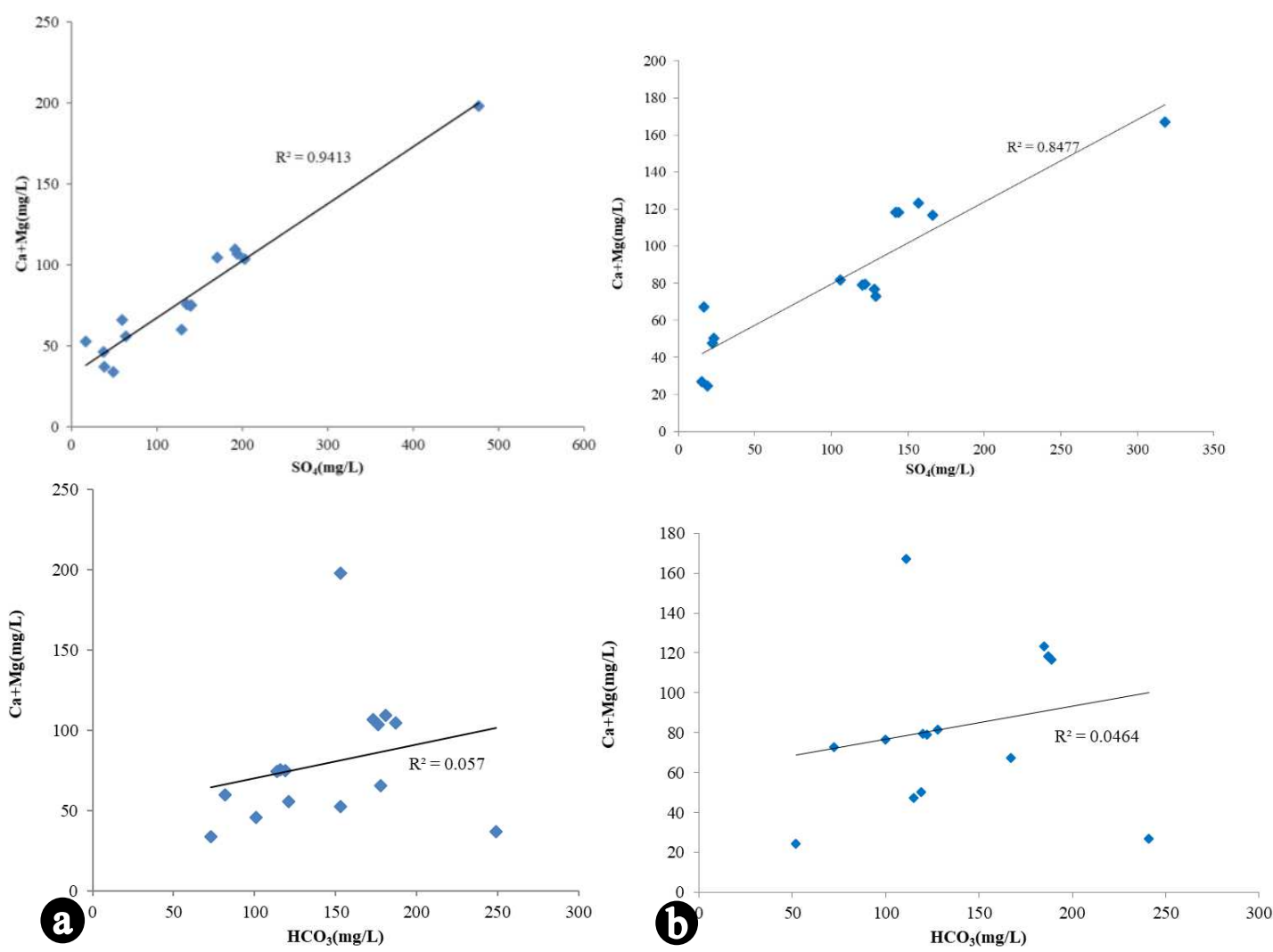

Fig. 4. plots of $\mathrm{Ca}^{2+}+\mathrm{Mg}^{2+}$ versus $\mathrm{SO}_{4}{ }^{2-}$ and $\mathrm{HCO}_{3}{ }^{-}$in the waters (a. dry season and b. wet season).

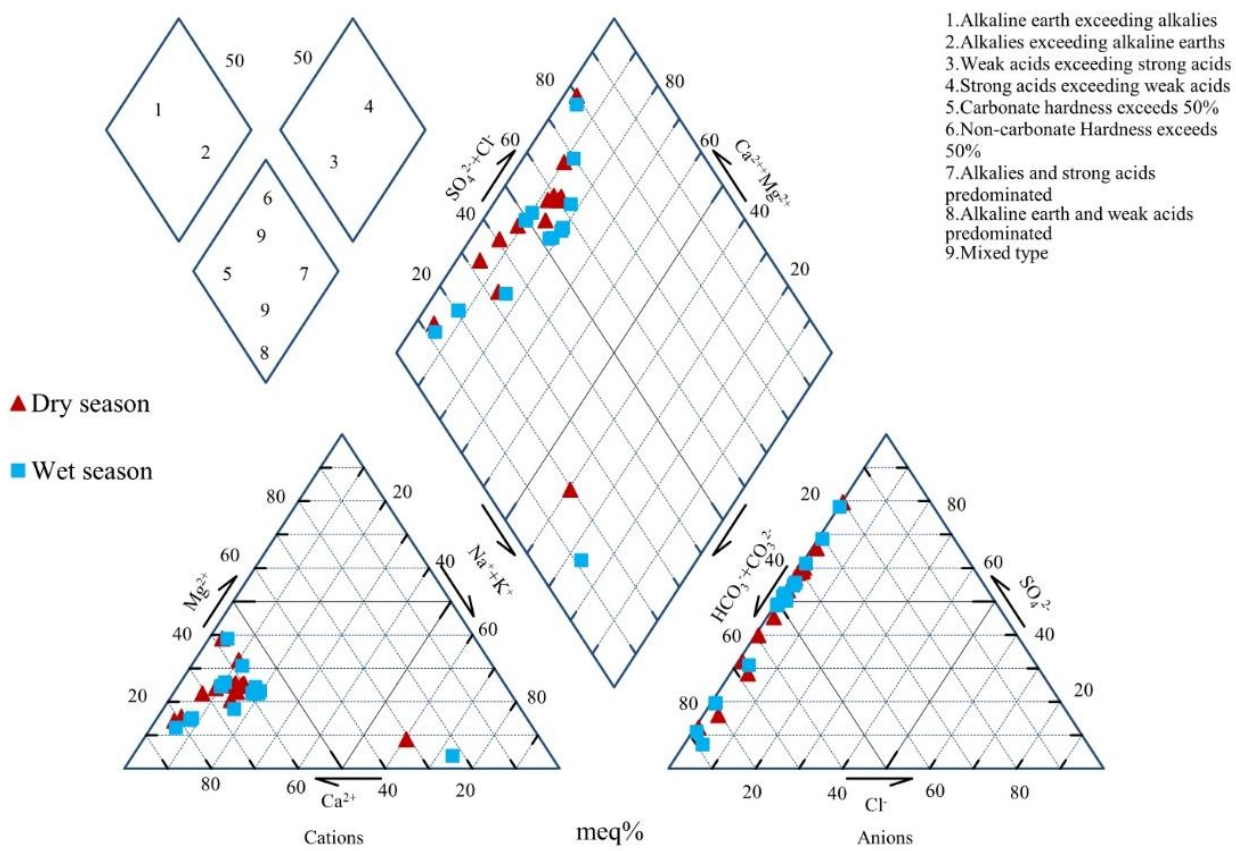

Fig. 5. Piper diagram showing the type of water samples.

The chemical contents of the major ions (Fig.6) in dry and wet season showed that the sulfate in the coal mine drainage sample (P3) was evidently higher than that of the other samples, and the concentrations of $\mathrm{Ca}^{2+}, \mathrm{Mg}^{2+}$, and $\mathrm{SO}_{4}^{2-}$ in the all groundwater samples were higher than the background values. This might have been due to the oxidation of the sulfides in the coal seams, such as in the case of pyrite $\left(\mathrm{FeS}_{2}\right)$ that produced the free acid that neutralized the carbonate minerals in the coal measures (Li, 2014). Carbonate minerals such as calcite, dolomite, iron dolomite and siderite are usually filled in coal fractures as epigenetic minerals (Ward, 2002), and this is mainly formed by the reaction of $\mathrm{CO}$ and $\mathrm{CO}_{2}$ produced during coalification with fluid in coal (Zhang, et 
al., 2020). The reaction can be explained as:

$$
\begin{aligned}
& 4 \mathrm{FeS}_{2} \text { (pyrite) }+14 \mathrm{H}_{2} \mathrm{O}+15 \mathrm{O}_{2} \rightarrow 4 \mathrm{Fe}(\mathrm{OH})_{3}+8 \mathrm{SO}_{4}{ }^{2-}+16 \mathrm{H}^{+} \\
& \mathrm{MgCa}\left(\mathrm{CO}_{3}\right)_{2}+4 \mathrm{H}^{+} \rightarrow \mathrm{Mg}^{2+}+\mathrm{Ca}^{2+}+2 \mathrm{H}_{2} \mathrm{O}+2 \mathrm{CO}_{2}
\end{aligned}
$$

The concentrations of the major ions in the stream water samples were higher than those of the groundwater samples, especially in the case of $\mathrm{HCO}_{3}{ }^{-}$and $\mathrm{Ca}^{2+}$. Due to the enclosure of the environment, the released $\mathrm{CO}_{2}$ from the above neutralization reaction further deepened the carbonate erosion (Zhang, 2016), which can be explained as:

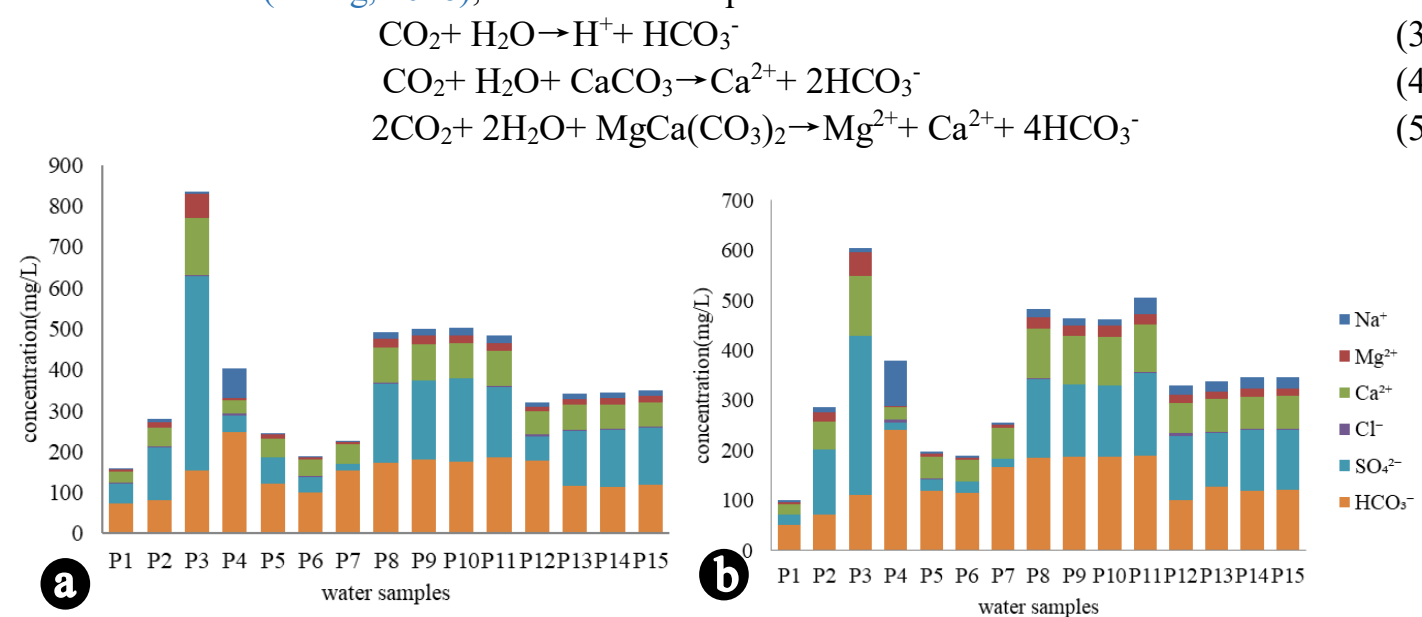

Fig. 6. Chemical content of major ions (a. dry season and b. wet season).
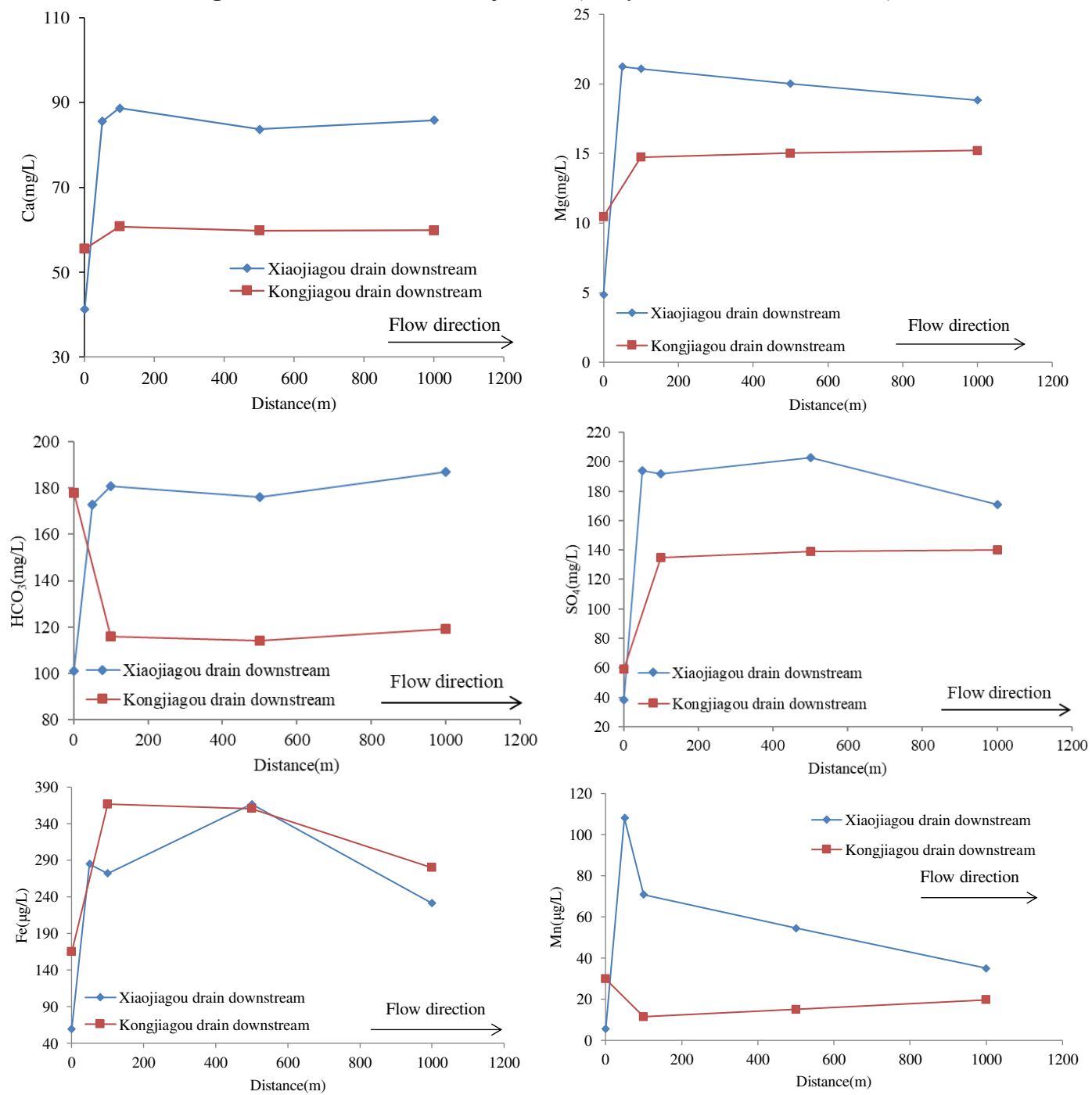

Fig. 7. Variation between the concentration of major ions and the distance downstream. 
Therefore, the type of $\mathrm{Ca} \cdot \mathrm{Mg}-\mathrm{HCO}_{3}$ groundwater was continuously discharged from the pithead, which increased the ionic concentration in the downstream drainage. It should be noted that the concentration of $\mathrm{SO}_{4}{ }^{2-}$ in the groundwater sample (P3) was $477 \mathrm{mg} / \mathrm{L}$ in dry season, which exceeded the limit value of $250 \mathrm{mg} / \mathrm{L}$ in the Chinese drinking water standard, hence, it was not suitable to be used as a drinking water source. However, the local residents still placed water pipes at the pithead to use as a drinking water source, which would have a certain impact on their health.

The variation in the major ionic concentrations from the coal mine drainage to the downstream area have been depicted in Fig. 7. Both in dry and wet season P6 and P12 were the background values taken from upstream of the drain, which were indicated at a distance of 0 . This showed that the concentration of most major ions was higher than the background values. However, the concentration of $\mathrm{HCO}_{3}{ }^{-}$in the $\mathrm{P} 12$ water sample was higher than that of the downstream water sample, indicating the presence of $\mathrm{Ca} \cdot \mathrm{Mg}-\mathrm{HCO}_{3}$ in the groundwater upstream of the Kongjiagou coal mine drainage, which was enriched with $\mathrm{HCO}_{3}{ }^{-}$. Compared to the background value, the concentration of Mn downstream of Kongjiagou showed little change. It can also be seen that the ion concentration was the largest at the beginning of the drain and gradually decreased with downstream distance. However, downstream of the Kongjiagou drain, the concentrations of $\mathrm{Mg}$, $\mathrm{SO}_{4}$, and $\mathrm{HCO}_{3}$ did not decrease with distance, but increased slightly. This may be due to the fact that Kongjiagou was a coal mine and was constantly discharging mine water into the river, resulting in the river water being in a state of ion enrichment for a long period of time. Hence, the coal mine drainage from the Xiaojiagou coal mine (P8) led to the enrichment in $\mathrm{Ca}, \mathrm{Mg}, \mathrm{SO}_{4}, \mathrm{HCO}_{3}, \mathrm{Fe}$, and $\mathrm{Mn}$. The high presence of these major ions exhibits the impact of the coal mine drainage on the water quality of the aquifer.

\subsubsection{Trace element concentrations of the water samples}

A total of 10 types of trace element concentrations, including zinc $(\mathrm{Zn})$, iron $(\mathrm{Fe})$, manganese (Mn), and aluminum (Al) etc. in each water sample have been summarized in Table 3. In addition, the water quality properties in the study area according to the Chinese Standards for Drinking Water Quality (GB 5749-2006) and the WHO (WHO, 2011) can be found in Table 3, which does not present the comparison between the ion concentrations of all the trace elements relative to the above two standards. However, it can be regarded as a general indication of the water quality state in the study area. Fe and Mn clearly exceeded the Chinese and WHO standards, while other trace elements were within the suitable limit. The five water samples with the exceeding Mn concentrations were P1, P2, P4, P5, and P8 in dry season. Among them, the concentration of Mn in the P2 water sample clearly exceeded the standard by reaching $1925.136 \mu \mathrm{g} / \mathrm{L}$. The concentration of Fe from the seven water samples of P1, P2, P5, P7, P10, P13, and P14 also exceeded the standard value in dry season, where the concentration of $\mathrm{Fe}$ in the $\mathrm{P} 2$ water sample was $8356.48 \mu \mathrm{g} / \mathrm{L}$, while $\mathrm{P} 1$ and $\mathrm{P} 5$ exhibited $1563.719 \mu \mathrm{g} / \mathrm{L}$ and $1112.564 \mu \mathrm{g} / \mathrm{L}$, respectively. The concentration of Fe in the stream water samples was approximately $300 \mu \mathrm{g} / \mathrm{L}$, while the excess content was less than $100 \mu \mathrm{g} / \mathrm{L}$ in dry season. However, only 2 samples with the exceeding Mn concentrations were P2, P4, while the concentration of Fe from the two water samples of P2, P11 in wet season, where the concentration of Fe in the P2 was $12872.882 \mu \mathrm{g} / \mathrm{L}$. The oxidation of the iron sulfide and aluminosilicate minerals by the acidic water was the main reason for the high concentrations of $\mathrm{Fe}$ and $\mathrm{Mn}$ in the coal mine drainage (Cravotta, 2005 and 2008; Sahoo, 2020). Thus, the reason for the high concentration of iron and manganese in P2 is that there were a lot of iron and manganese oxides at the pithead when the mine was abandoned.

Excessive Fe and Mn content in drinking water would have adverse effects on the human body, where Fe can affect the cardiovascular system, while Mn can affect the central nervous system as well as brain and reproductive functions, causing anorexia, vomiting, and diarrhea. According to the evaluation based on the Chinese standards for ground water quality (GB 14848-2017), the P2 groundwater sample was classified as a class $\mathrm{V}$ groundwater sample because of the $\mathrm{Fe}$ and $\mathrm{Mn}$ contents exceeding $2000 \mu \mathrm{g} / \mathrm{L}$ and $1500 \mu \mathrm{g} / \mathrm{L}$, respectively, which would not be suitable for drinking.

\subsubsection{Distribution of solutes}

Box and whisker plots represented the concentrations of the major elements (Fig. 8). The median was plotted near the center with log boxes of the different parameters that indicated the maximum number of parameters in the normal distribution. The exception was the non-normal distribution of $\mathrm{SO}_{4}, \mathrm{~K}, \mathrm{Na}$, and $\mathrm{Mg}$. The imbalance in $\mathrm{SO}_{4}$ was mainly due to the large amount of 
AMD that was produced by the abandoned mines in the oxidation environment, where AMD was discharged into the downstream rivers. These results showed that in dry season the concentration of $\mathrm{SO}_{4}$ in P3 and P8-P11 in the groundwater sample was $477 \mathrm{mg} / \mathrm{L}$ and $200 \mathrm{mg} / \mathrm{L}$, respectively, while the concentration of $\mathrm{Na}^{+}$in the $\mathrm{P} 4$ groundwater sample was as high as $71.12 \mathrm{mg} / \mathrm{L}$, which was much higher than in other water samples, resulting in the non-normal distribution, also appeared the same phenomenon in wet season The collected water samples were mainly from the coal mine drainage at the pithead and from the river water downstream of the drain. These water samples were from the hills, wasteland, alluvial plain, and underground mines in the study area. Land use and cover patterns can directly affect the water and chemical properties of the study area. Therefore, the variation in these parameters would appear not normally distributed, which could be caused by the impact of coal mining as well as agricultural and domestic waste.

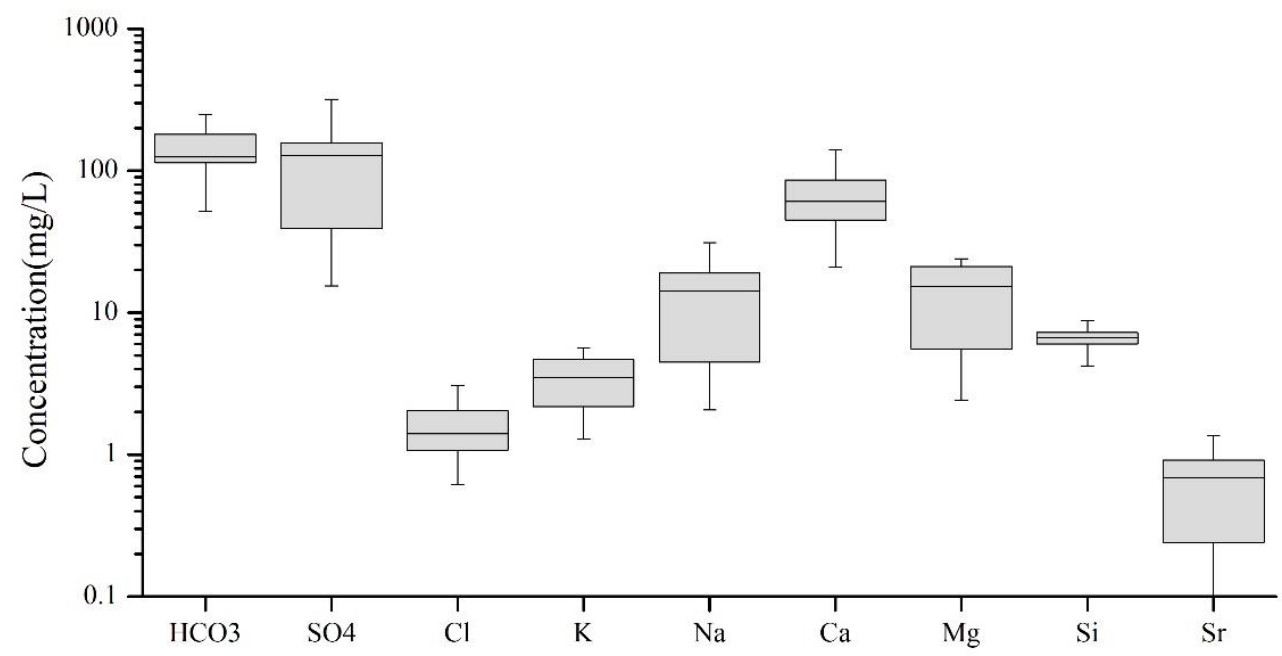

Fig. 8. Box plots for the concentration of major elements.

\subsubsection{Statistical analysis}

A total of 8 variables across 15 samples were used to analyze the correlations therein. The correlation matrix results, including the physicochemical parameters, have been summarized in Table 4, where the $\mathrm{pH}$ was found to be negatively correlated with $\mathrm{Ca}^{2+}$. The EC was positively correlated with $\mathrm{HCO}_{3}^{-}, \mathrm{SO}_{4}^{2-}, \mathrm{Mg}^{2+}$, and $\mathrm{Ca}^{2+}$, while $\mathrm{HCO}_{3}^{-}$was positively correlated with $\mathrm{Cl}^{-}$and $\mathrm{Na}^{+}$and $\mathrm{SO}_{4}{ }^{2-}$ was positively correlated with $\mathrm{Ca}^{2+}$ and $\mathrm{Mg}^{2+}$. In addition, $\mathrm{Cl}^{-}$was positively correlated with $\mathrm{Na}^{+}$, while $\mathrm{Ca}^{2+}$ was positively correlated with $\mathrm{Mg}^{2+}$. Moreover, strong positive correlations were observed between $\mathrm{EC}$ and $\mathrm{SO}_{4}{ }^{2-}, \mathrm{EC}$ and $\mathrm{Ca}^{2+}, \mathrm{EC}$ and $\mathrm{Mg}^{2+}, \mathrm{HCO}_{3}{ }^{-}$and $\mathrm{Na}^{+}$, $\mathrm{SO}_{4}{ }^{2-}$ and $\mathrm{Ca}^{2+}, \mathrm{SO}_{4}{ }^{2-}$ and $\mathrm{Mg}^{2+}, \mathrm{Cl}^{-}$and $\mathrm{Na}^{+}$as well as $\mathrm{Ca}^{2+}$ and $\mathrm{Mg}^{2+}$. Some moderate and positive correlations were also observed in between $\mathrm{HCO}_{3}{ }^{-}$and $\mathrm{Cl}^{-}$.

$\mathrm{F} 1$ was positively correlated with the $\mathrm{EC}, \mathrm{SO}_{4}{ }^{2-}, \mathrm{Ca}^{2+}$, and $\mathrm{Mg}^{2+}$ and negatively correlated with the $\mathrm{pH}$ (Table 5), while explaining 52\% of the data variance. Moreover, the F1 that was correlated with the $\mathrm{SO}_{4}{ }^{2-}$ resulted in a higher overall concentration, which could be related to the sulfide minerals, while the positive correlation between $\mathrm{F} 1$ and both $\mathrm{Ca}^{2+}$ and $\mathrm{Mg}^{2+}$ also indicated that a large amount of the carbonate minerals was dissolved in the process of the atmospheric precipitation moving underground through the surface. At the same time, F1 displayed a negative correlation with most of the dissolved minerals and the $\mathrm{pH}$. When the concentration of those dissolved minerals increased, the $\mathrm{pH}$ value decreased. These observations were mainly found in the context of AMD (Pope, 2010). Therefore, the F1 factor can be considered an indicator of the AMD effect. Furthermore, the F2 factor was positively correlated with $\mathrm{HCO}_{3}^{-}, \mathrm{Cl}^{-}$, and $\mathrm{Na}^{+}$(Table 5), which explained $29 \%$ of the data variance and was correlated with the ions that characterized the carbonate minerals. The $\mathrm{Na}^{+}$and $\mathrm{Cl}^{-}$ions were mainly produced by precipitation, human activities, and the dissolution of silicates. In the studied case, a strong positive correlation was observed between $\mathrm{Na}^{+}$ and $\mathrm{Cl}^{-}$, which indicated a strong degree of dissolution evaporation in this area. Consequently, F2 can be considered an indicator of halite dissolution. Hence, F1 can represent the high concentrations of $\mathrm{SO}_{4}{ }^{2-}, \mathrm{Ca}^{2+}, \mathrm{Mg}^{2+}$, and low $\mathrm{pH}$ in the abandoned coal mine drainage, while $\mathrm{F} 2$ can represent the relationships between the drainage and the $\mathrm{HCO}_{3}^{-}, \mathrm{Na}^{+}$, and $\mathrm{Cl}^{-}$concentrations in downstream rivers. 
Table 4

Correlation matrix of physico-chemical parameters in waters.

\begin{tabular}{|c|c|c|c|c|c|c|c|c|}
\hline & $\mathrm{pH}$ & $\mathrm{EC}$ & $\mathrm{HCO}_{3}{ }^{-}$ & $\mathrm{SO}_{4}{ }^{2-}$ & $\mathrm{Cl}^{-}$ & $\mathrm{Na}^{+}$ & $\mathrm{Ca}^{2+}$ & $\mathrm{Mg}^{2+}$ \\
\hline $\mathrm{pH}$ & 1 & & & & & & & \\
\hline $\mathrm{EC}$ & -0.396 & 1 & & & & & & \\
\hline $\mathrm{HCO}_{3}^{-}$ & -0.135 & 0.421 & 1 & & & & & \\
\hline $\mathrm{SO}_{4}{ }^{2-}$ & -0.363 & $0.948^{* * *}$ & 0.119 & 1 & & & & \\
\hline $\mathrm{Cl}^{-}$ & 0.06 & -0.077 & $0.554^{*}$ & -0.304 & 1 & & & \\
\hline $\mathrm{Na}^{+}$ & 0.221 & 0.141 & $0.740^{* * *}$ & -0.119 & $0.690^{* * *}$ & 1 & & \\
\hline $\mathrm{Ca}^{2+}$ & -0.488 & $0.943^{* * *}$ & 0.284 & $0.942^{* *}$ & -0.293 & -0.143 & 1 & \\
\hline $\mathrm{Mg}^{2+}$ & -0.351 & $0.939^{* *}$ & 0.124 & $0.990^{* *}$ & -0.266 & -0.142 & $0.936^{* *}$ & 1 \\
\hline
\end{tabular}

* Correlation is significant at the 0.05 level

** Correlation is significant at the 0.01 level

Table 5

Factor loadings in waters.

\begin{tabular}{llll}
\hline & $\mathrm{F} 1$ & $\mathrm{~F} 2$ & Communalities \\
\hline $\mathrm{pH}$ & $\mathbf{- 0 . 5 0 8}$ & 0.067 & 0.263 \\
$\mathrm{EC}$ & $\mathbf{0 . 9 7}$ & 0.21 & 0.986 \\
$\mathrm{HCO}_{3}{ }^{-}$ & 0.27 & $\mathbf{0 . 8 7 7}$ & 0.842 \\
$\mathrm{SO}_{4}{ }^{2-}$ & $\mathbf{0 . 9 7 2}$ & -0.088 & 0.952 \\
$\mathrm{Ca}^{2+}$ & $\mathbf{0 . 9 8 5}$ & -0.034 & 0.754 \\
$\mathrm{Mg}^{2+}$ & $\mathbf{0 . 9 6 5}$ & -0.083 & 0.869 \\
$\mathrm{Cl}^{-}$ & -0.248 & $\mathbf{0 . 8 3 2}$ & 0.972 \\
$\mathrm{Na}^{+}$ & -0.084 & $\mathbf{0 . 9 2 8}$ & 0.939 \\
Eigenvalues & 4.192 & 2.384 & \\
$\%$ of variance explained & 52.405 & 29.805 & \\
Cumulative \% of variance & 52.405 & 82.211 & \\
\hline
\end{tabular}

Loading values for the PC axis higher than +0.5 and lower than -0.5 are given in bold.

\subsection{Stream sediment samples}

\subsubsection{The geochemistry of stream sediments}

The concentrations of the metals and metalloids in the seven stream sediment samples near the mine drain were measured (Table 6) and displayed with box and whisker plots of the concentration of each element (Fig. 9). The concentrations of $\mathrm{Al}(\%), \mathrm{Ca}(\%), \mathrm{Mg}(\%), \mathrm{Fe}(\%)$, and $\mathrm{Mn}(\mathrm{ppm})$ in the two streams that were downstream of the drain were quite different. The concentration of $\mathrm{Ca}$ in the stream sediments downstream of the Xiaojiagou drain was an average of 3-4 times higher than in Kongiagou, while the concentration of $\mathrm{Mg}$ in the downstream stream sediments of the Kongjiagou drain was higher than in Xiaojiagou. This demonstrated that a large amount of carbonate minerals was present in the stream sediments. These minerals were produced by the leaching of groundwater into the karst aquifer, which was later discharged. It is worth noting that the concentrations of $\mathrm{Fe}, \mathrm{Mn}, \mathrm{Cr}$, and $\mathrm{Zn}$ downstream of the Kongjiagou drain were evidently higher than those in Xiaojiagou, while the concentration of Mn was 5-6 times higher. This clearly shows that the Xiaojiagou coal mine was closed, while the Kongjiagou coal mine is still active. With mining activities, a large amount of metal minerals would be discharged and deposited downstream of the coal mine drainage, affecting the water and soil quality. In addition, the concentrations of $\mathrm{Fe}$ and $\mathrm{Mn}$ oxides in the anoxic zone were relatively low, while the concentrations of the dissolved Fe and $\mathrm{Mn}$ in the interstitial water were increased accordingly (Tarutis et al., 1992).

Compared to the average background values in a low mountain or hilly area (Shi et al., 2016), the concentrations of $\mathrm{Pb}, \mathrm{P}$, and $\mathrm{Ti}$ in the seven samples were similar to the background values, while the concentrations of $\mathrm{Cr}, \mathrm{Mn}, \mathrm{Ni}, \mathrm{Zn}, \mathrm{Al}, \mathrm{Fe}$, and $\mathrm{Mg}$ in the stream sediments downstream of the Kongjiagou drain were higher than the background values and the concentrations of $\mathrm{Fe}$ and $\mathrm{Mn}$ ions were 3-4 times higher than the background values. The samples (S1-S3) taken from downstream of the Xongjiagou drain were all below the background values. This showed that with continuous 
mining activities, a large amount of $\mathrm{Fe}$ and and $\mathrm{Mn}$ oxides were discharged into the downstream river along with the coal mine drainage, resulting in the enrichment of Fe and Mn elements in the downstream sediments. The closure of the coal mine was beneficial to the recovery of the local environment and has a clearly positive ecological effect.

Table 6

Concentrations of metals and metalloids of stream sediments near the mine drain. All values are in ppm, except for $\mathrm{Al}_{2} \mathrm{O}_{3}, \mathrm{CaO}, \mathrm{Fe}_{2} \mathrm{O}_{3}$ and $\mathrm{MgO}(\%)$.

\begin{tabular}{ccccccccc}
\hline & $\mathrm{S} 1$ & $\mathrm{~S} 2$ & $\mathrm{~S} 3$ & $\mathrm{~S} 4$ & $\mathrm{~S} 5$ & $\mathrm{~S} 6$ & $\mathrm{~S} 7$ & $\mathrm{NSB}$ \\
\hline $\mathrm{Cr}$ & 33 & 44.06 & 33.74 & 62.74 & 51.08 & 56.77 & 69.93 & 62 \\
$\mathrm{Mn}$ & 388.16 & 615.94 & 355.02 & 2197.05 & 2402.7 & 2111.49 & 1428.9 & 640 \\
$\mathrm{Co}$ & 14.11 & 14.78 & 21.33 & 16.52 & 17.2 & 18.76 & 19.58 & 12 \\
$\mathrm{Ni}$ & 18.35 & 21.56 & 15.3 & 28.8 & 26.5 & 44.91 & 43.78 & 25 \\
$\mathrm{Cu}$ & 22.44 & 23.07 & 85.26 & 27.44 & 24.43 & 24.37 & 30.92 & 21 \\
$\mathrm{Zn}$ & 49.89 & 56.23 & 48.04 & 81.56 & 74.56 & 91.39 & 101.99 & 70 \\
$\mathrm{Rb}$ & 51.39 & 65.58 & 65.43 & 95.68 & 80.74 & 86.11 & 108.95 & $/$ \\
$\mathrm{Sr}$ & 344.76 & 285.27 & 127.52 & 136.2 & 163.78 & 172.61 & 157.08 & 83 \\
$\mathrm{~Pb}$ & 19.53 & 17.74 & 19.37 & 23.8 & 21.87 & 22.84 & 27.67 & 25 \\
$\mathrm{P}$ & 442.6 & 480.5 & 285.7 & 548 & 489.7 & 447.8 & 603.1 & 521 \\
$\mathrm{Ti}$ & 1825 & 2157 & 2446 & 3671 & 3349 & 3601 & 4328 & 4222 \\
$\mathrm{Al}{ }_{2} \mathrm{O}_{3}$ & 7.869 & 8.334 & 7.686 & 13.9 & 11.55 & 13.3 & 15.33 & 13.1 \\
$\mathrm{CaO}$ & 19.85 & 16.18 & 4.76 & 4.52 & 5.73 & 5.19 & 3.48 & 0.8 \\
$\mathrm{Fe}_{2} \mathrm{O}_{3}$ & 2.37 & 3.82 & 2.69 & 6.37 & 5.05 & 5.84 & 6.74 & 4.4 \\
$\mathrm{MgO}$ & 0.68 & 0.84 & 0.63 & 1.36 & 1.24 & 1.29 & 1.42 & 1.1 \\
\hline $\mathrm{NSB}: \mathrm{Ch}$
\end{tabular}

NSB: China stream sediments background value (Shi, et al., 2016)

Furthermore, the concentrations of $\mathrm{Co}, \mathrm{Cu}, \mathrm{Sr}$, and $\mathrm{Ca}$ in all the samples exceeded the background values, in which the concentration of $\mathrm{Cu}$ in sample $\mathrm{S} 3$ was as high as $85.26 \mathrm{ppm}$, which may be caused by agricultural activities, while the concentrations of $\mathrm{Sr}$ and $\mathrm{Ca}$ in samples $\mathrm{S} 1$ and S2 downstream of the Xongjiagou drain were much higher than those of other samples, indicating that carbonate dissolution took place in the Xiaojiagou coal mine. These phenomena could be explained by the dissolution and the precipitation of the minerals during stream sedimentation and mine drainage. Hence, according to the standard environmental quality evaluation for soil analysis (GB 15618-1995), all seven stream sediment samples had good quality soil, reflecting the secondary standard of environmental quality. This type of soil would be suitable for planting and animal husbandry, in which the soil quality would not cause harm and pollution to the environment.
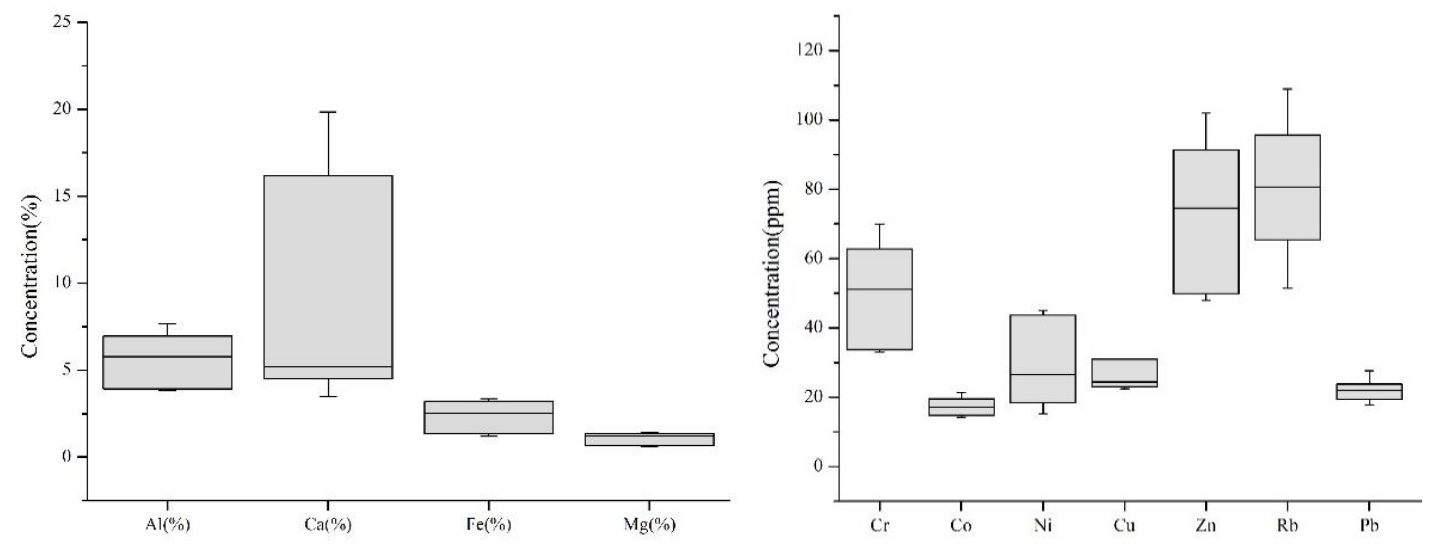

Fig. 9. Box plots for the concentration of metals and metalloids.

\subsubsection{Statistical analysis}

The correlation matrix of the stream sediment samples (Table 7) highlighted that $\mathrm{Cr}$ had a strongly positive correlation with $\mathrm{Zn}, \mathrm{Rb}, \mathrm{Pb}, \mathrm{Ti}, \mathrm{Al}, \mathrm{Fe}$, and $\mathrm{Mg}$, and a moderately positive correlation with $\mathrm{Ni}$ and $\mathrm{P}$. Moreover, Mn had a strongly positive correlation with $\mathrm{Mg}$ as well as a 
moderately positive correlation with $\mathrm{Ti}, \mathrm{Al}$, and $\mathrm{Fe}$. Co had a strongly negative correlation with $\mathrm{Sb}$ and a moderately negative correlation with $\mathrm{Sr}$ and $\mathrm{Ca}$. Furthermore, $\mathrm{Ni}$ had a strongly positive correlation with $\mathrm{Zn}$ and $\mathrm{Al}$ as well as a moderately positive correlation with $\mathrm{Rb}, \mathrm{Pb}, \mathrm{Ti}, \mathrm{Fe}$, and $\mathrm{Mg}$. In addition, $\mathrm{Zn}$ had a strongly positive correlation with $\mathrm{Rb}, \mathrm{Pb}, \mathrm{Ti}, \mathrm{Al}, \mathrm{Fe}$, and $\mathrm{Mg}$. Additionally, $\mathrm{Rb}$ had a strongly positive correlation with $\mathrm{Pb}, \mathrm{Ti}, \mathrm{Al}, \mathrm{Fe}$, and $\mathrm{Mg}$ as well as a moderately negative correlation with $\mathrm{Ca}$. Sr had a strongly positive correlation with $\mathrm{Ca}$, while Ti had a strongly positive correlation with $\mathrm{Al}, \mathrm{Fe}$, and $\mathrm{Mg}$ as well as a moderately positive correlation with $\mathrm{Ca}$. Finally, $\mathrm{Al}$ had a strongly positive correlation with $\mathrm{Fe}$ and $\mathrm{Mg}$, while $\mathrm{Fe}$ had a strongly positive correlation with $\mathrm{Mg}$. Hence, the stream sediment correlations reflected the adsorption capacity of $\mathrm{Fe}, \mathrm{Mn}$, and $\mathrm{Al}$ oxides in the metals and metalloids within the surface environment (Neiva, et al., 2014). This also highlighted the coal mine drainage's influence, because the concentrations of $\mathrm{Fe}, \mathrm{Zn}, \mathrm{Mn}, \mathrm{Cr}, \mathrm{Al}$, and $\mathrm{Mg}$ in the stream sediments that were directly obtained from the coal mine drainage were the highest (Table 6).

Table 7

Correlation matrix in stream sediments from the study area.

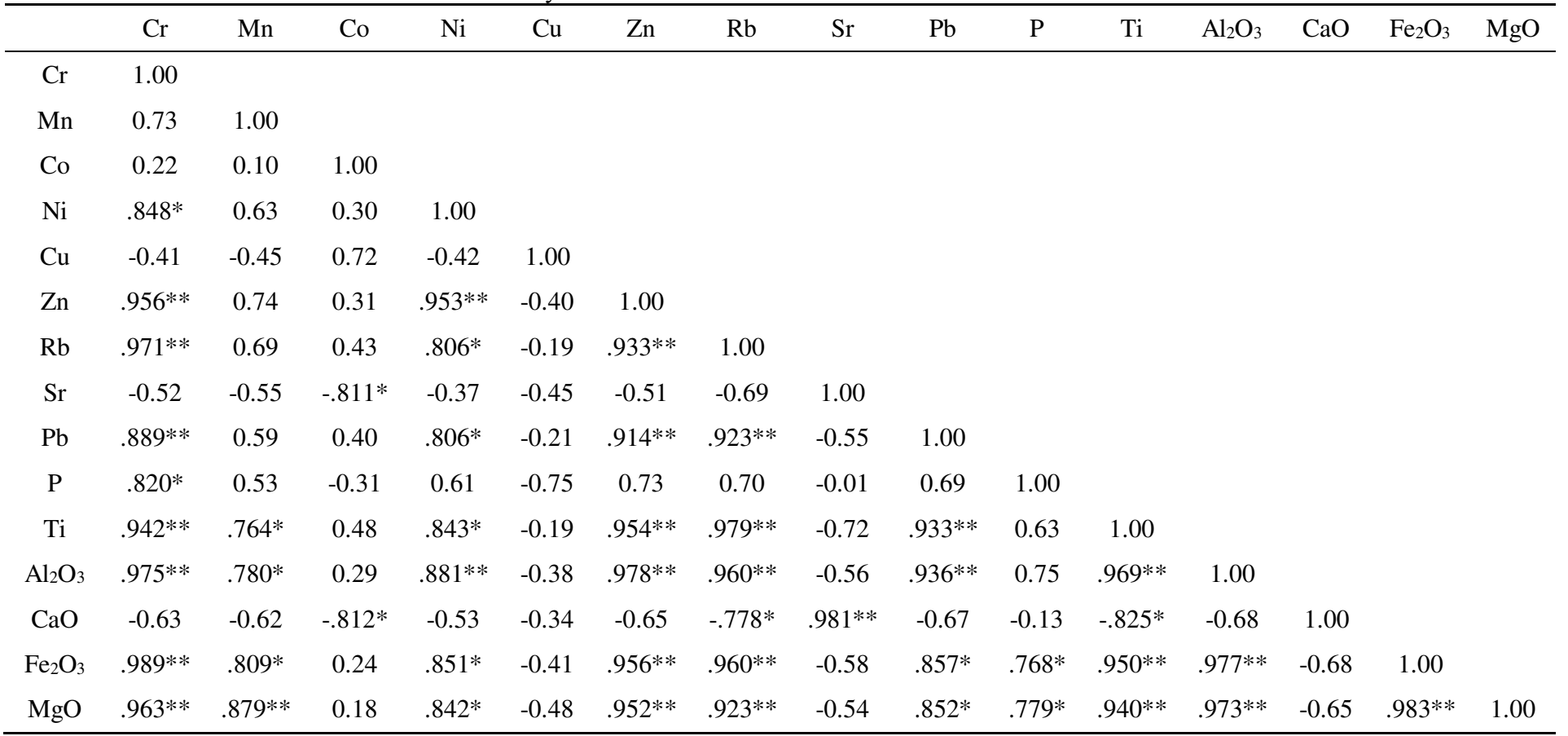

* Correlation is significant at the 0.05 level

** Correlation is significant at the 0.01 level

\subsubsection{Correlations with the coal mine drainage}

Through the data analysis summarized in Tables 1,2, and 6, the closure of the Xiaojiagou coal mine caused the groundwater to remain in the abandoned mine channel longer than in the Kongjiagou coal mine. In addition, these groundwater samples had a weak acid environment ( $\mathrm{pH}$ values between 6.54 to 6.68 ), which was more conducive to the dissolution of carbonate minerals in the groundwater. Therefore, the concentrations of $\mathrm{Ca}^{2+}$ and $\mathrm{Mg}^{2+}$ in the water samples downstream of Xiaojiagou (P8-P11) were significantly higher than in the downstream water samples (P12-P15). This phenomenon directly led to the increased $\mathrm{Ca}$ content in the downstream stream sediments to be far higher than the background value, where the concentrations of Ca in Xiaojiagou were larger than in Kongjiagou. During the mining process, a large number of minerals containing $\mathrm{Fe}$ and $\mathrm{Mn}$ elements were dissolved or suspended in the groundwater along with the discharged mine water inflow, forming downstream stream sediments (Neiva, et al., 2019). As a result, Fe and Mn contents in the stream sediments (S4-S7) in the lower reaches of Kongjiagou were much higher than the background values.

XRD analysis was performed on two selected stream sediment samples (S1 and S4). Mineral phases, such as quartz and cuprite can be found in both samples (Fig. 10). Magnetite and delafossite, which are characteristic of weathering mining wastes, indicates the possible presence of various mineral phases of environmental interest (Alejandro, et al., 2021). Muscovite and pyrite were 
detected in each sample, which shows the coal mine drainage brought these minerals from strata into stream. Calcite was the major mineral phases in S1, and belonged to the waste rock deposit from Xiaojiagou coal mine.

Generally speaking, the concentrations of metals and metalloids in the stream sediments were affected by the coal mine drainage and were generally enriched in $\mathrm{Cr}, \mathrm{Mn}, \mathrm{Zn}, \mathrm{Sr}, \mathrm{Co}, \mathrm{Ni}, \mathrm{Cu}, \mathrm{Al}$, $\mathrm{Ca}, \mathrm{Fe}$, and $\mathrm{Mg}$. Amongst them, the concentrations of $\mathrm{Mn}, \mathrm{Ca}$, and $\mathrm{Fe}$ were significantly increased. This demonstrated a strong positive correlation between the concentrations of trace elements in the coal mine drainage and the stream sediments.
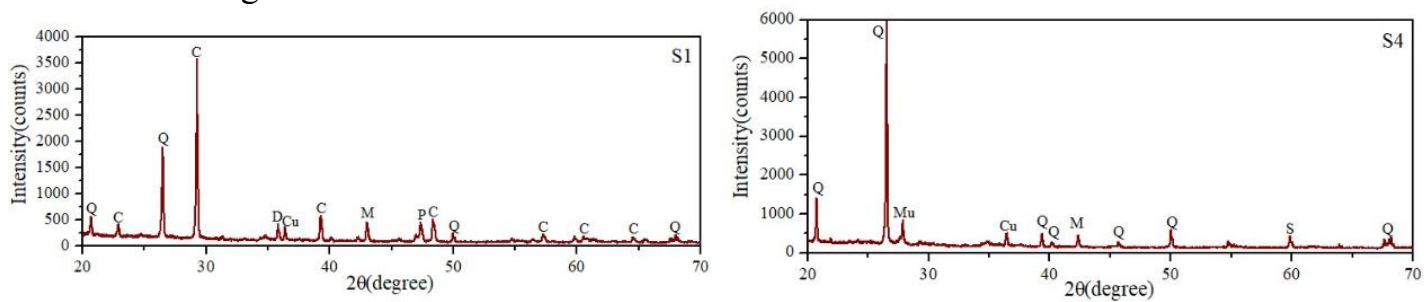

Fig. 10. The X-ray diffraction patterns of stream sediment samples. C-Calcite; $\mathrm{Cu}$-Cuprite; D-Delafossite; MMagnetite; Mu-Muscovite; P-Pyrite; Q-Quartz; S-Siderophyllite

\section{Conclusions}

Mining activities can change the chemical properties of the groundwater environment from being reducing to oxidizing, in which pyrite was oxidized, a large amount of AMD was produced, and the average $\mathrm{pH}$ value was less than 6 (Lambert, et al., 2004). With the closure of these coal mines, the groundwater continuously pours into the closed mining space, resulting in a reducing groundwater environment that ceases the oxidation of pyrite. Therefore, the $\mathrm{pH}$ values of the groundwater samples from the seven abandoned mines in the study area are between 6.36 to 7.17. With a large amount of coal mine drainage being discharged into the river, the $\mathrm{pH}$ of the downstream stream samples of the two drains are of weak acidity. Moreover, the compound effect of the carbonate dissolution and evaporation processes indicate that the correlation between $\mathrm{Ca}^{2+}$ and $\mathrm{Mg}^{2+}$ relative to $\mathrm{SO}_{4}{ }^{2-}$ and $\mathrm{HCO}_{3}^{-}$is appropriate. Most of the groundwater and stream samples in dry and wet season are dominated by $\mathrm{Ca} \cdot \mathrm{Mg}-\mathrm{HCO} 3$ and $\mathrm{Ca} \cdot \mathrm{Mg}-\mathrm{Cl}$, respectively. In the mining site, with the dissolution of carbonate and sulfate, a large amount of $\mathrm{Ca}^{2+}, \mathrm{Mg}^{2+}$, and $\mathrm{SO}_{4}{ }^{2-}$ is present in the groundwater and stream samples that are higher than the background value.

With respect to Chinese standard and the WHO's guidelines, the Dazhu coal mine area contain good quality water in terms of its physical and chemical properties, except for the $\mathrm{Mn}$ and $\mathrm{Fe}$ concentrations, especially in the groundwater samples, which exceed the standard limits for drinking water in China of $100 \mu \mathrm{g} / \mathrm{L}$ and $300 \mu \mathrm{g} / \mathrm{L}$ with $1925.136 \mu \mathrm{g} / \mathrm{L}$ and $12872.882 \mu \mathrm{g} / \mathrm{L}$, respectively. In addition, PCA highlight the $\mathrm{SO}_{4}{ }^{2-}, \mathrm{Ca}^{2+}, \mathrm{Mg}^{2+}$, and low $\mathrm{pH}$ group as well as the $\mathrm{HCO}_{3}^{-}, \mathrm{Na}^{+}$, and $\mathrm{Cl}^{-}$group that likely reflect the AMD effects as well as human activities and the evaporation occurring in low mountains and hills, respectively.

Due to the continuous drainage of the Kongiagou coal mine, the $\mathrm{Fe}$ and $\mathrm{Mn}$ oxides are dissolved in the groundwater and discharged into the downstream current, enriching the $\mathrm{Fe}, \mathrm{Mn}, \mathrm{Cr}$, and $\mathrm{Zn}$ ions in the stream sediments. The average concentrations of $\mathrm{Mn}$ and $\mathrm{Fe}$ in the downstream Kongjiagou drain sediment samples are $2035.03 \mathrm{ppm}$ and 6\%, respectively, which are higher relative to the $\mathrm{Mn}$ and $\mathrm{Fe}$ concentrations in Xiaojiagou of $453.04 \mathrm{ppm}$ and 2.96\%, respectively. Both $\mathrm{Mn}$ and $\mathrm{Fe}$ concentrations are found to be higher than the background values, while all the samples (S1 to S3) from the downstream Xongjiagou drain are all below the background values. However, all seven stream sediment samples display good quality, reflecting the secondary standard of environmental quality. In summary, long-term monitoring and management during mining activities is required to ensure a safe domestic water supply, while maintaining economic development. At the same time, mine closures can be conducive to ecological and environmental recovery.

\section{Acknowledgments:}

Financial supports from key research and development project of Sichuan Province (No. 2018JY0425 and 2018SZ0290).

\section{References}

Alejandro Rodríguez-Hern'andez, Isabel L'azaro, Israel Razo, et al., 2021. Geochemical and mineralogical 
characterization of stream sediments impacted by mine wastes containing arsenic, cadmium and lead in NorthCentral Mexico. Journal of Geochemical Exploration. 106707.

Amari K E, Valera P, Hibti M, et al., 2014. Impact of mine tailings on surrounding soils and ground water: Case of Kettara old mine, Morocco. Journal of African Earth Sciences. 100, 437-449.

Baioumy H M, 2005. Preliminary data on cadmium and arsenic geochemistry for some phosphorites in Egypt. Journal of African Earth Sciences, 41, 266-274.

Cravotta III, C.A., 2005. Effects of abandoned coal-mine drainage on streamflow and water quality in the Mahanoy Creek Basin, Schuylkill, Columbia, and Northumberland Counties, Pennsylvania, 2001. U.S. Geological Survey. Scientific Invest. Rep. 2004-5291.

Cravotta III, C.A., 2008. Dissolved metals and associated constituents in abandoned coal-mine discharges, Pennsylvania, USA. Part 1: Constituent quantities and correlations. Appl. Geochem. 23, 166-202.

Davis, J.C., Sampson, R.J., 1986. Statistics and Data Analysis in Geology. John Wiley \& Sons, Inc., pp. 166-171.

Du P P, 2011. Research on geologic environment effects induced by coal mining in ecological weakness area and assessment techniques: a case study taking Yushenfu mining district in northern Shanxi Province. China University of Mining and Technology, Xuzhou.

Hou D Y, O'Connor D, Nathanail P, Li T, Ma Y, 2017. Integrated GIS and multivariate statistical analysis for regional scale assessment of heavy metal soil contamination: A critical review. Environmental Pollution. 231(pt. 1), $1188-1200$.

Hu W Y, Zhou J J, Yan L Y, 2010. Study on environment and safety disasters from abandoned coal mines. Journal of Xi'an University of Science and Technology. 30(04), 436-440.

Jiang L, 2016. The Sedimentary environment and coal accumulating pattern of Jingang coalfield in Dazhou. Chengdu University of Technology, Chengdu.

Jiang Q C, 2009. Impact and assessment of Zhenfoshan coal mining of Dazhou on water environment. Acta Mineralogica Sinica. 29(S1),398-399.

Katrina J E, Thomas M G, Jillian F B, 1999. Seasonal variations in microbial populations and environmental conditions in all extreme acid mine drainage environment. Appl Environ Microbiol. 65(8), 3627-3632.

Kissao G U, Heinz J T, 2003. Distribution patterns of rare-earth elements and uranium in tertiary sedimentary phosphorites of Hahoto-Kpogam, Togo. Journal of African Earth Sciences, 37, 1-10.

Lambert D C, Mcdonough K M, Dzombak D A, et al., 2004. Long-term changes in quality of discharge water from abandoned underground coal mines in Uniontown Syncline, Fayette County, PA, USA. Water Research. 38(2), 277-288.

Lghoul, M., Maqsoud, A., Hakkou, R., Kchikach, A., 2014. Hydrogeochemical behavior around the abandoned Kettara mine site, Morocco. J. Geochem. Explor. 144, 456-467.

Li M B, Wu H, 2018. Coal seam physical property and coal quality characteristics of Jingang coal mine in Dazhou city, Sichuan province. Modern Mining. 34(11), 41-45.

Li T, 2014. Study on groundwater pollution risk assessment of abandoned coal mine. China University of Mining and Technology, Xuzhou.

Li Y J, 2014. Sequence-palaeogeography and coal accumulation of the late triassic Xujiahe formation in the Sichuan basin. China University of Mining and Technology, Beijing.

Lu Y T, Tang C, Chen J, et al., 2016. Assessment of major ions and heavy metals in groundwater: a case study from Guangzhou and Zhuhai of the Pearl River Delta, China. Frontiers of Earth Sciences. 10,340-351.

Lv H, Liu H L, Ma Z M et al., 2005. Formation and influential factors of Zibo city Hongshan and Zhaili coalmines underground water cross strata pollution. Coal Geology of China. 17(4), 24-27, 31.

McDonough K M, Lambert D C, Mugunthan P, 2005. Processes governing flow and chemical characteristics of discharges from free-draining, underground coal mines. Journal of Environmental Engineering. 131(4), 1361 1368.

Mohanty A K , Lingaswamy M , Rao V G, et al., 2018.Impact of acid mine drainage and hydrogeochemical studies in a part of Rajrappa coal mining area of Ramgarh District, Jharkhand State of India. Groundwater for Sustainable Development. 7, 164-175.

Mostert M M, Ayoko G A, Kokot S, 2010. Application of chemometrics to analysis of soil pollutants. TrAC Trends in Analytical Chemistry. 29(5), 430-445.

Narváez, J., Richter P, Toral M, 2007. Preliminary physical chemical characterization of river waters and sediments affected by copper mining activity in Central Chile: application of multivariate analysis. Journal of the Chilean Chemical Society. 52(3), 1261-1265.

Neiva, A.M.R., Carvalho, P.C.S., Antunes, I.M.H.R., Albuquerque, M.T.D., Santos, A.C.S., Cunha, P.P., Henriques, S.B.A., 2019. Assessment of metal and metalloid contamination in the waters and stream sediments around the abandoned uranium mine area from Mortorios, central Portugal. J. Geochem. Explor. 202, 35-48.

Neiva, A.M.R., Carvalho, P.C.S., Antunes, I.M.H.R., Silva, M.M.V.G., Santos, A.C.T., Cabral Pinto, M.M.S., Cunha, P.P., 2014. Contaminated water, stream sediments and soils close to the abandoned Pinhal do Souto uranium mine, Central Portugal. J. Geochem. Explor. 136, 102-117.

Piper, A.M., 1944. A graphical procedure in the chemical interpretation of groundwater analysis. Trans. Am. Geophys. Union. 25, 914-923.

Pope J, Newman N, Craw D, et al., 2010. Factors that influence coal mine drainage chemistry West Coast, South Island, New Zealand. New Zealand Journal of Geology and Geophysics.53, 115-128.

Qin W J, Han D M, Song X F, Engesgaard P, 2019. Effects of an abandoned Pb-Zn mine on a karstic groundwater reservoir. Journal of Geochemical Exploration. 200, 221-233.

Sahoo S, Khaoash S, 2020. Impact assessment of coal mining on groundwater chemistry and its quality from 
Brajrajnagar coal mining area using indexing models. Journal of Geochemical Exploration, 215, 106559.

Salomão G N, Dall'Agnol R, Sahoo P K, et al., 2020. Geochemical mapping in stream sediments of the Carajás Mineral Province: Background values for the Itacaiúnas River watershed, Brazil. Applied Geochemistry.104608.

Shi C Y, Liang M, Feng B, 2016. Average background values of 39 chemical elements in stream sediments of China. Earth Science.41(2), 234-251.

Tarutis W J, Unz R F, Brooks R P, et al., 1992. Behavior of sedimentary Fe and Mn in a natural wetland receiving acidic mine drainage, Pennsylvania, U.S.A. Applied Geochemistry. 7(1), 77-85.

Ward C.R., 2002. Analysis and significance of mineral matter in coal seams. International Journal of Coal Geology. $135-168$.

WHO (World Health Organization), 2011. Guidelines for Drinking-Water Quality, fourth ed.

Wu Q, Li S P, 2018. Positive and negative environmental effects of closed mines and its countermeasures. Journal of China Coal Society. 43(1), 21-32.

Xu G Q, Yue M, Yan J P, et al.,2007. Analysis on chemical property of acid mine water and prevention in Sitai coal mine. Coal Science and Technology. 35(9), 106-108.

Zeng R S, Zhuang X G, Koukouzas N, et al, 2005. Characterization of trace elements in sulphur-rich Late Permian coals in the Heshan coal field, Guangxi, South China. International Journal of Coal Geology, 61, 87-95.

Zhang B H, 2016. Study on ecological environmental effect of coal mine closure:a case study of zaozhuang coal mining area. Shandong Normal University. phd thesis.

Zhang N, Xu Y, Ning S Z, et al.,2020. Mineralogical Characteristics in the No. 6 Coal Seam from the Xiaohuangshan coal mine of Fukang Mining Area, Junggar Coal field. Coal science and Technology.1-11.

Zhang Q X, Zhou J W, Lin S H, et al., 2015. Characteristics and causes of groundwater pollution after HongshanZhaili mine closure in Zibo. Safety and Environment Engineering. 22(11), 23-28.

Zhou J J, Hu W Y, Zhang Z L, 2006. Analysis on rule of groundwater movement and model establishment of current numerical simulation in abandoned mines. Journal of China Coal Society. 31, 74-77. 

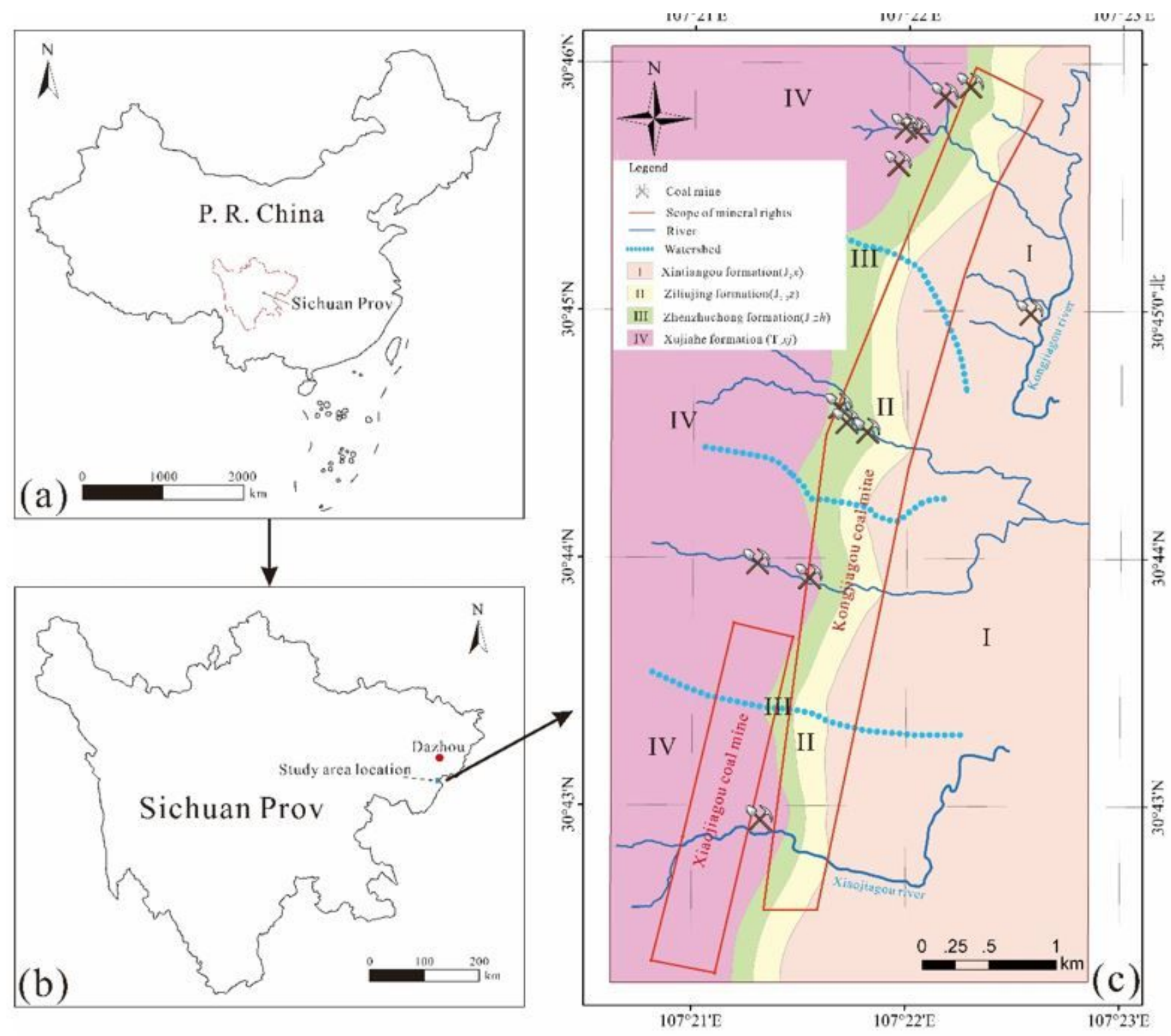

Figure 1

(a) the Sichuan Province in China, (b) location of study area in Sichuan Province, (c) geological and hydrogeological map of study area. Note: The designations employed and the presentation of the material on this map do not imply the expression of any opinion whatsoever on the part of Research Square concerning the legal status of any country, territory, city or area or of its authorities, or concerning the delimitation of its frontiers or boundaries. This map has been provided by the authors. 

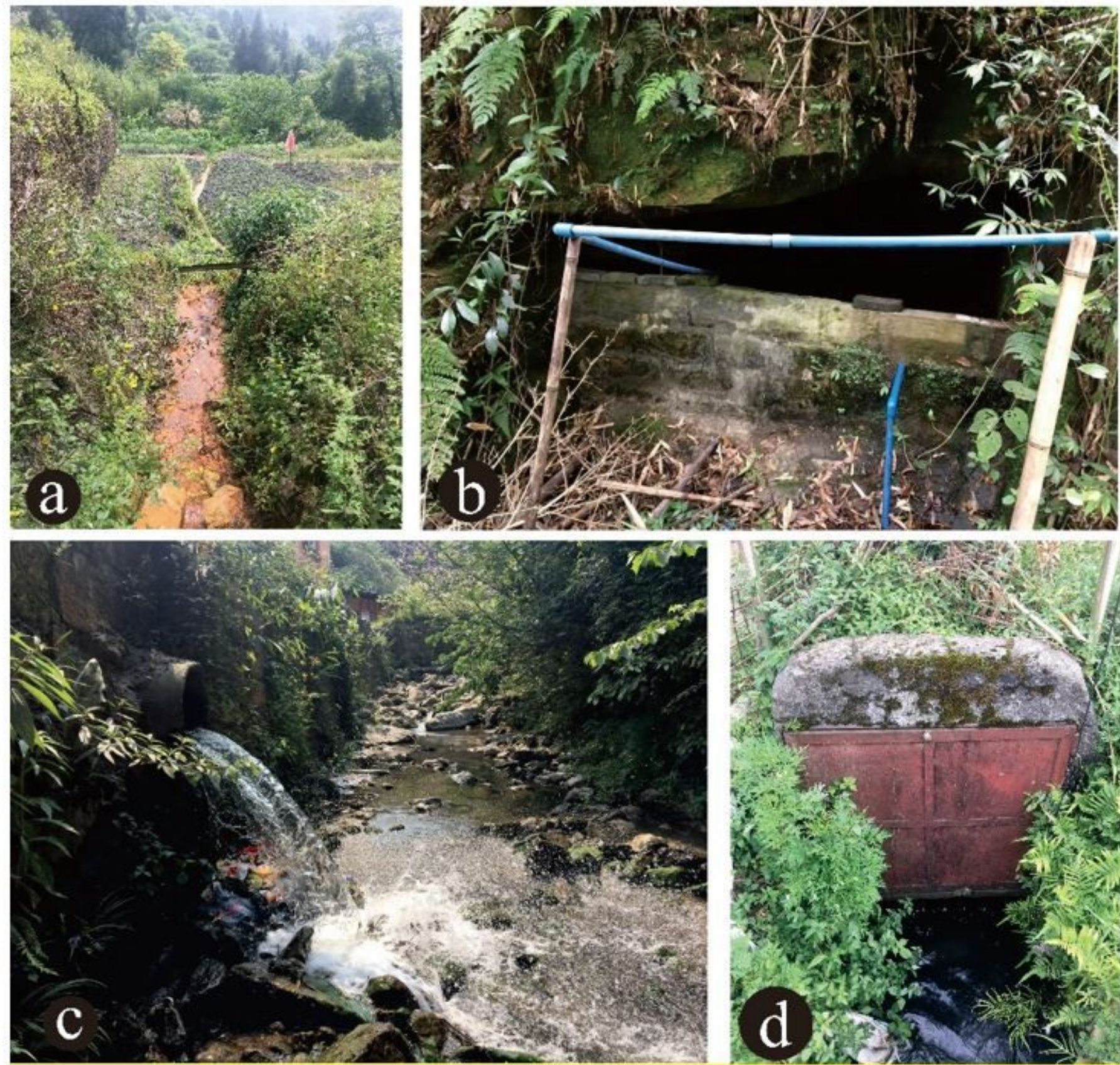

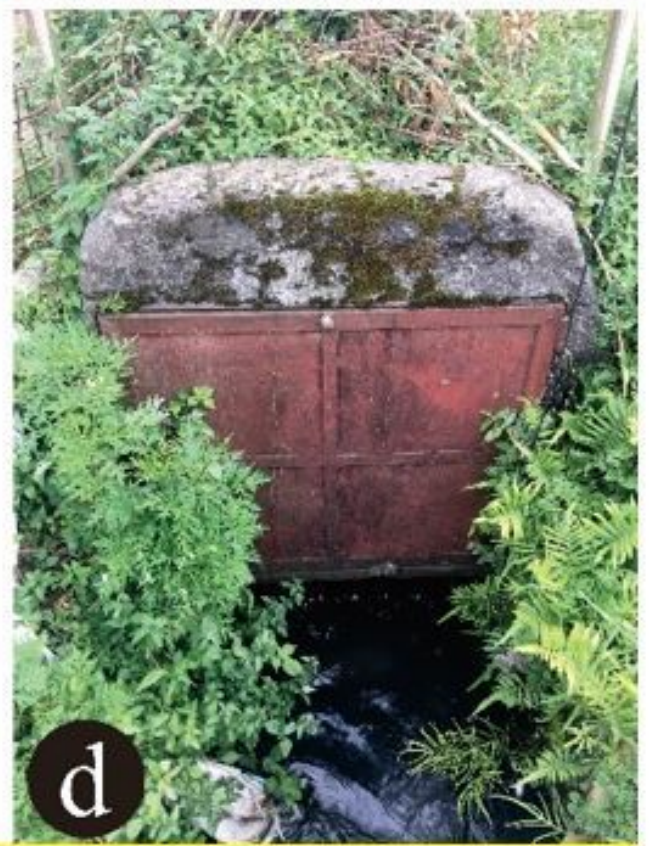

Figure 2

The study area: (a) coal mine drainage for agriculture, (b) pipes at the pithead, (c) drain of Xiaojiagou coal mine, (d) drain of Kongjiagou coal mine. 


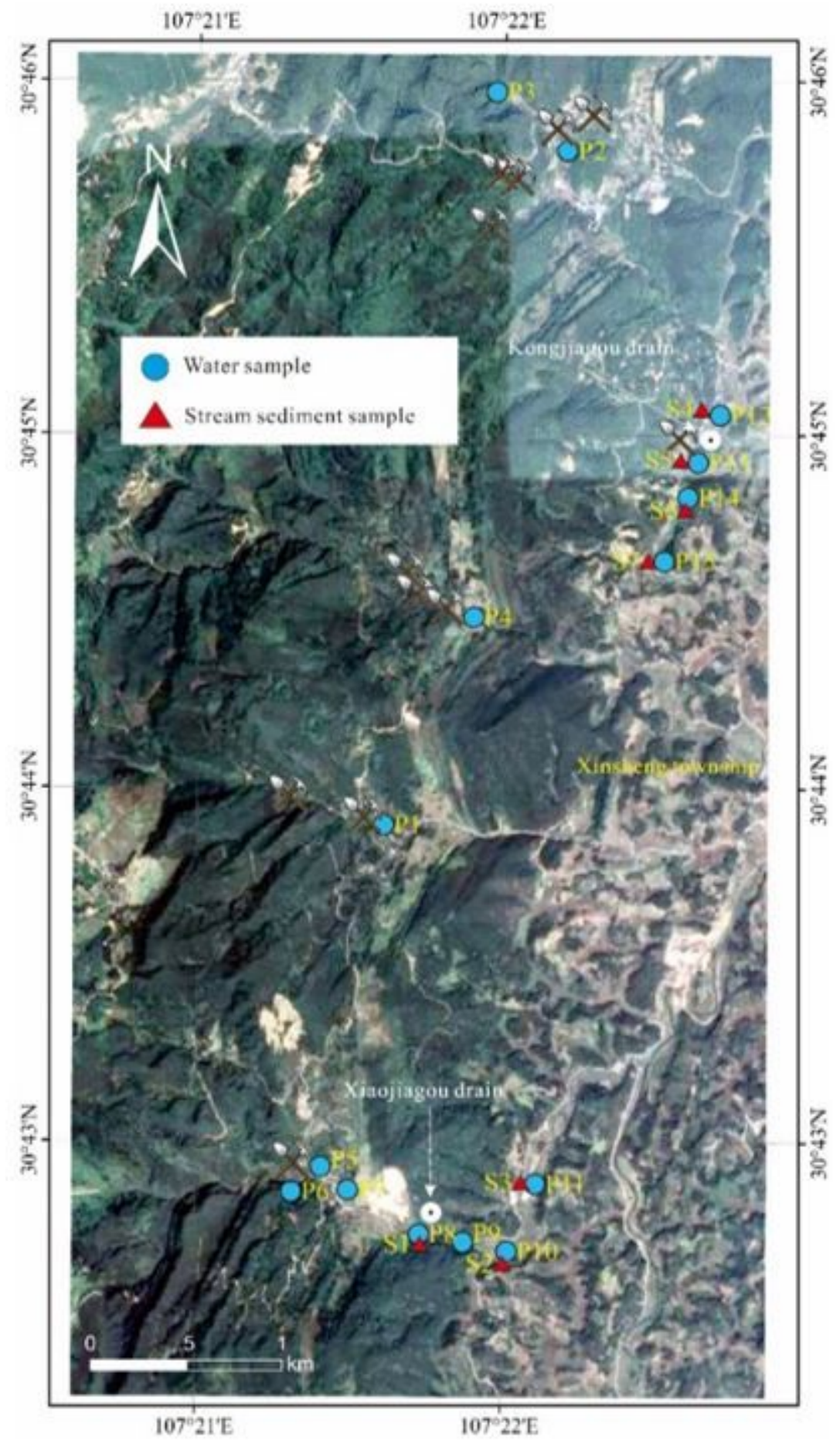

\section{Figure 3}

Distribution of samples in the study area Note: The designations employed and the presentation of the material on this map do not imply the expression of any opinion whatsoever on the part of Research Square concerning the legal status of any country, territory, city or area or of its authorities, or concerning the delimitation of its frontiers or boundaries. This map has been provided by the authors. 

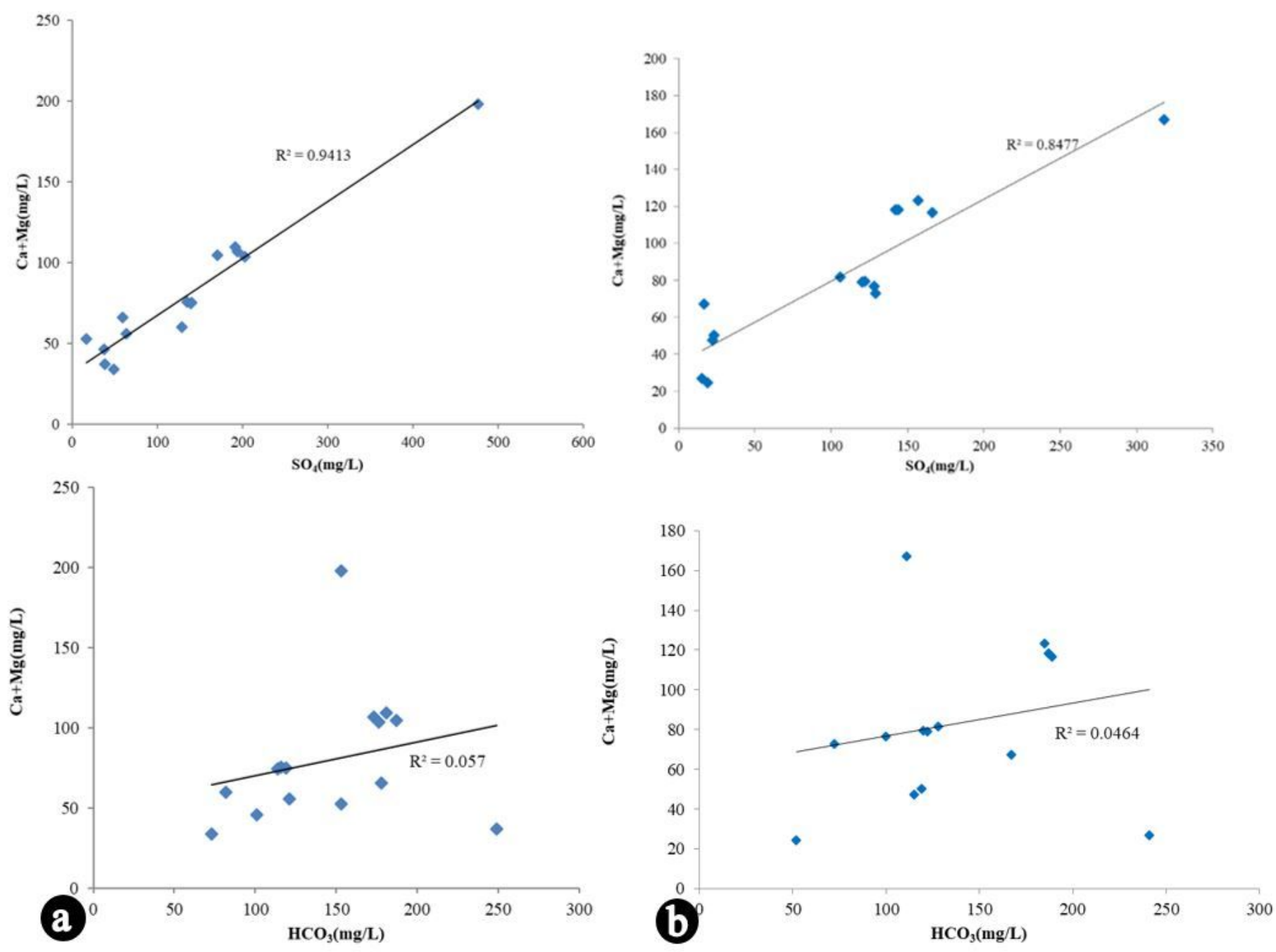

Figure 4

plots of $\mathrm{Ca} 2++\mathrm{Mg} 2+$ versus SO42- and $\mathrm{HCO} 3-$ in the waters (a. dry season and b. wet season). 


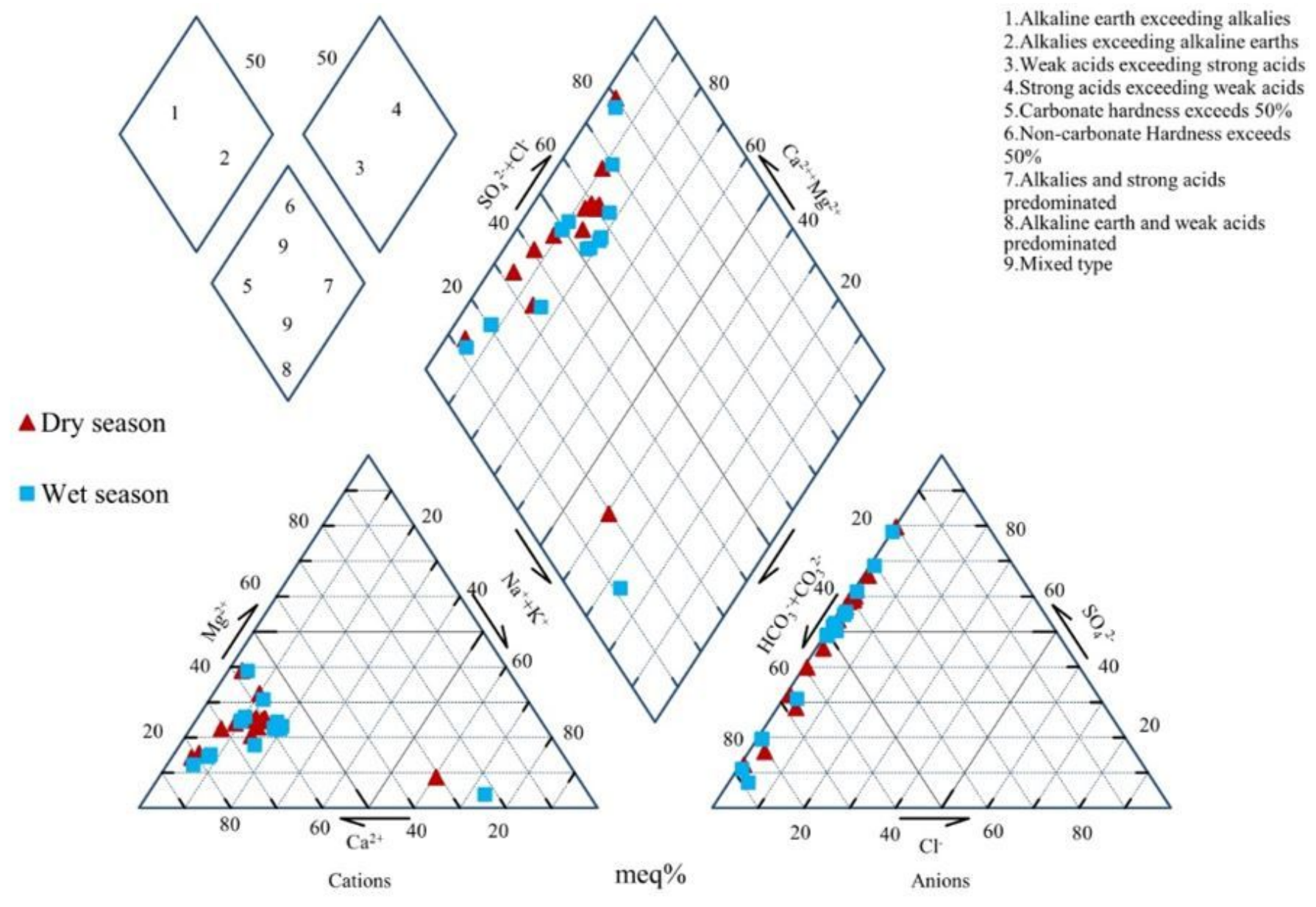

Figure 5

Piper diagram showing the type of water samples.
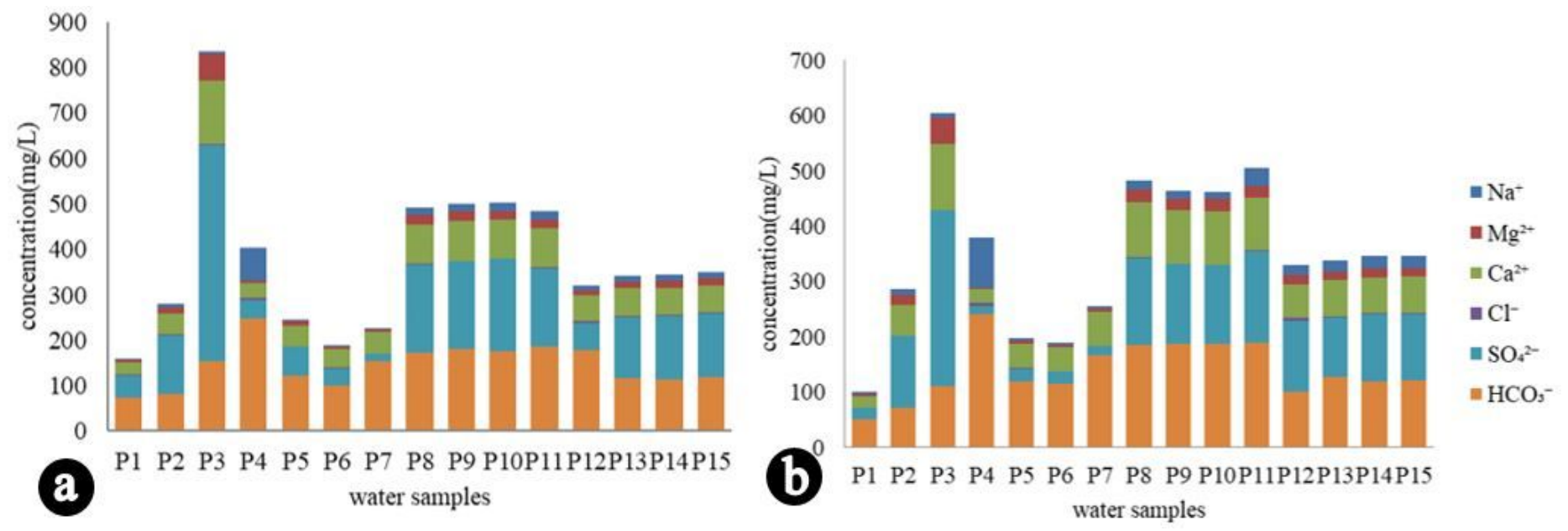

\section{Figure 6}

Chemical content of major ions (a. dry season and b. wet season). 

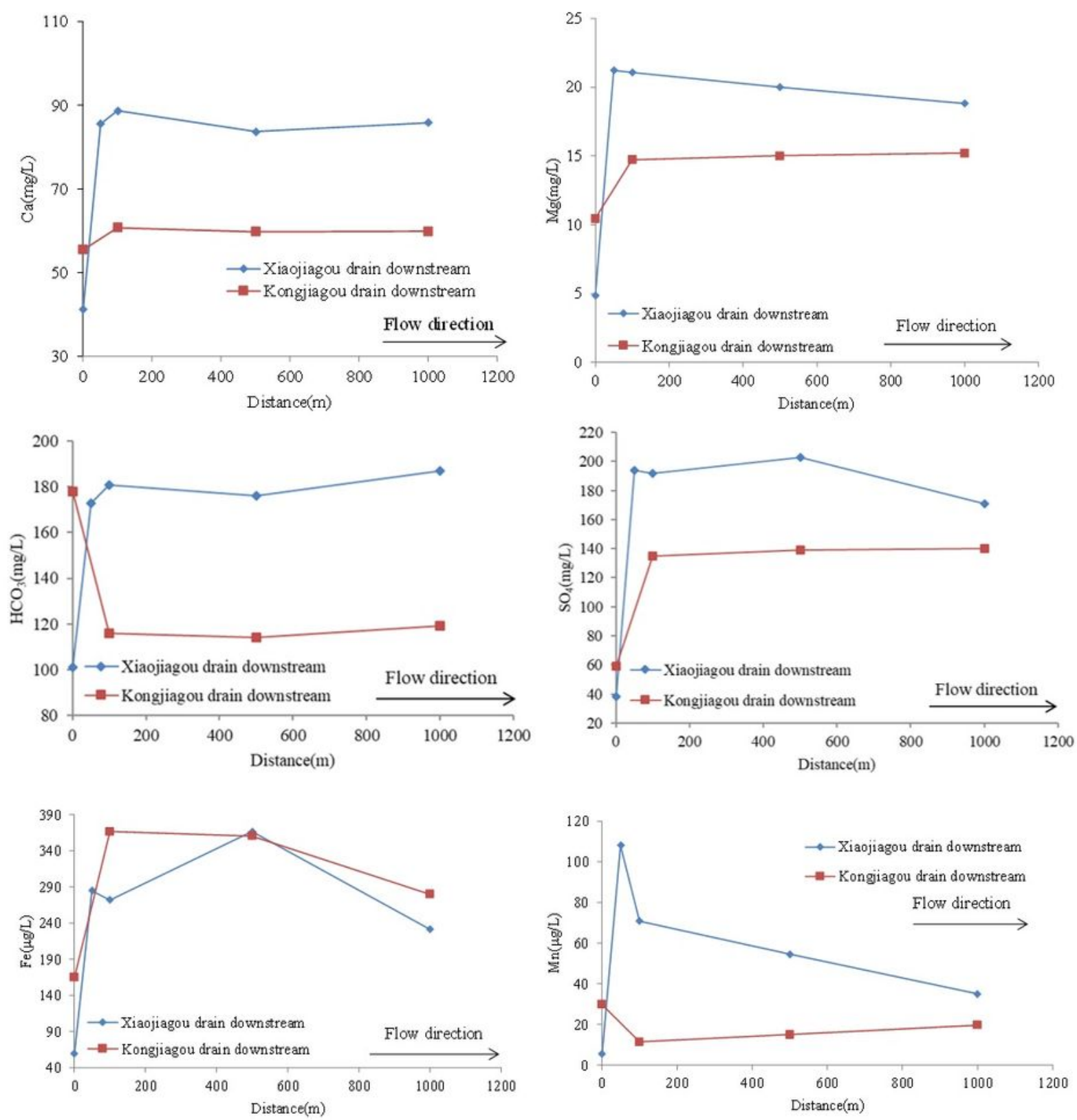

\section{Figure 7}

Variation between the concentration of major ions and the distance downstream. 


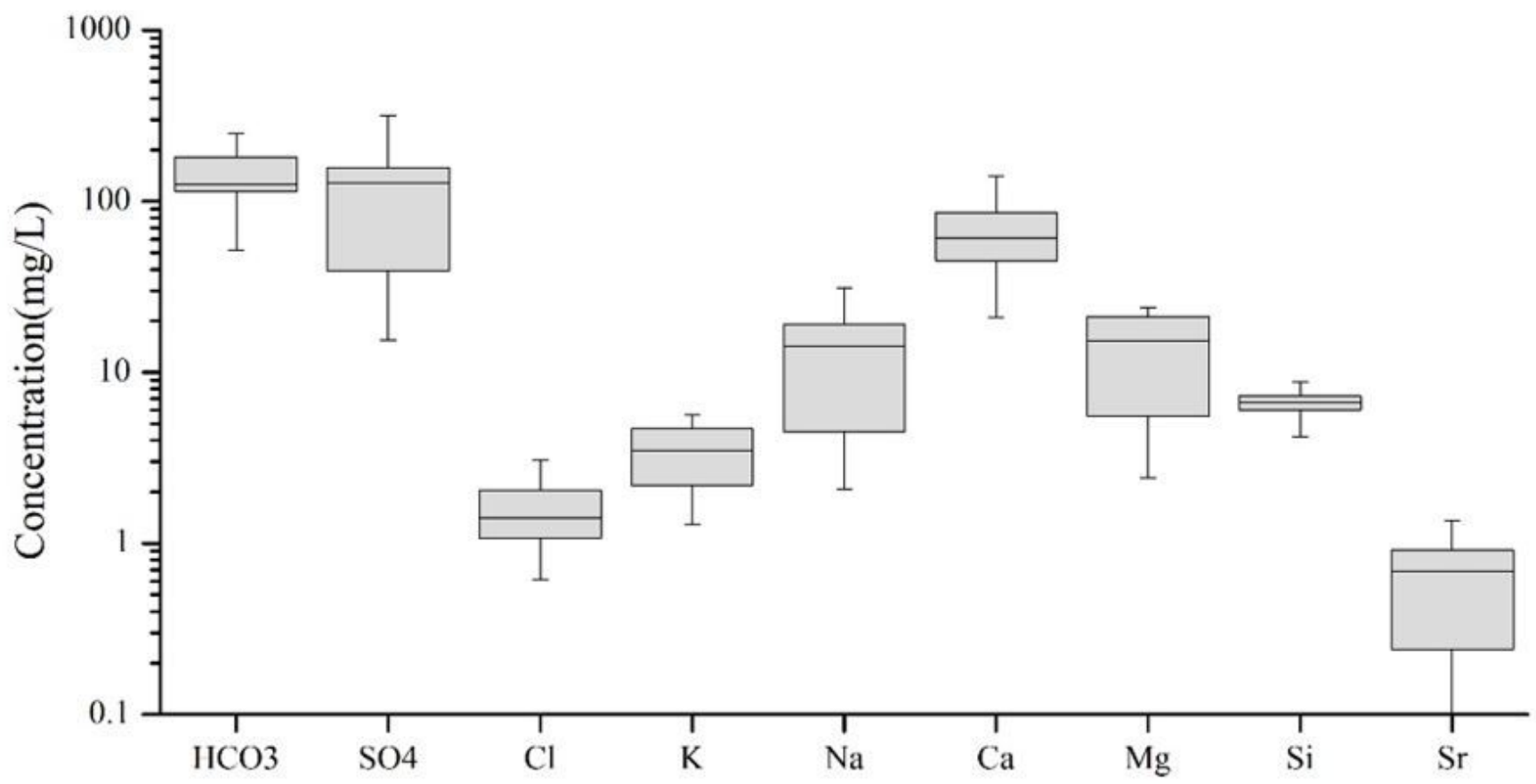

Figure 8

Box plots for the concentration of major elements.
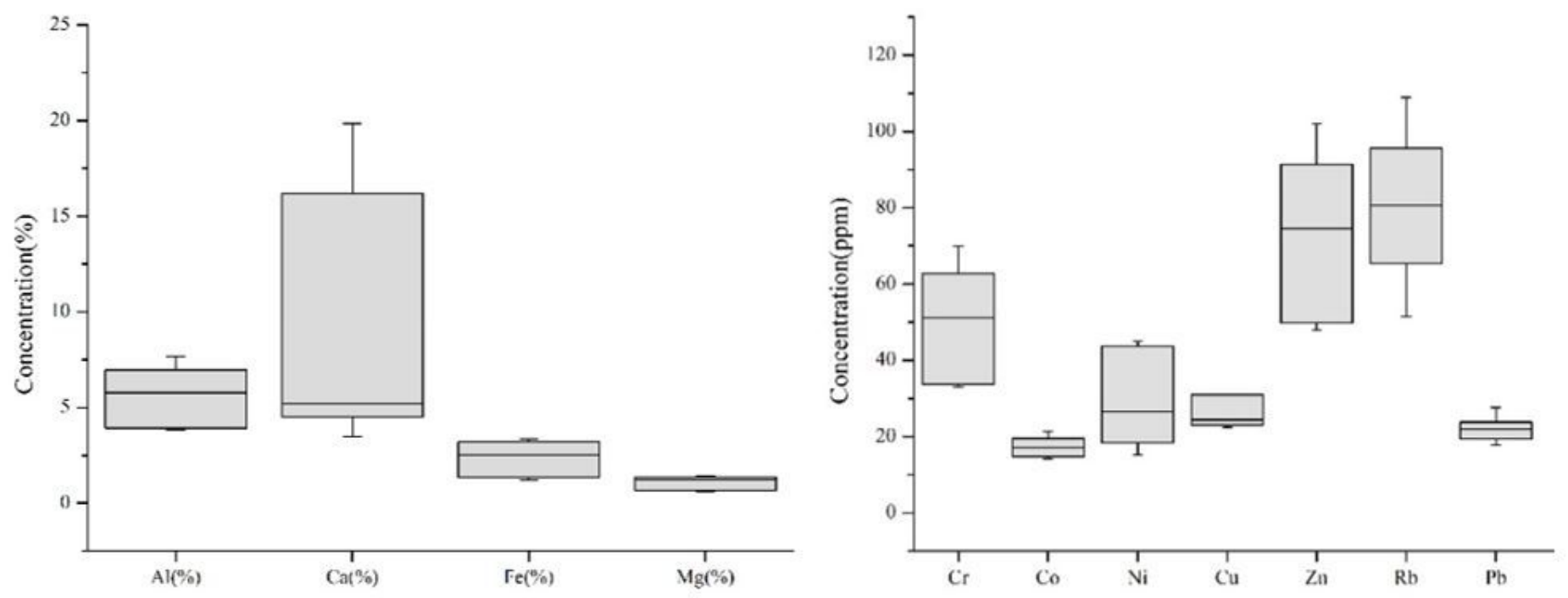

Figure 9

Box plots for the concentration of metals and metalloids.
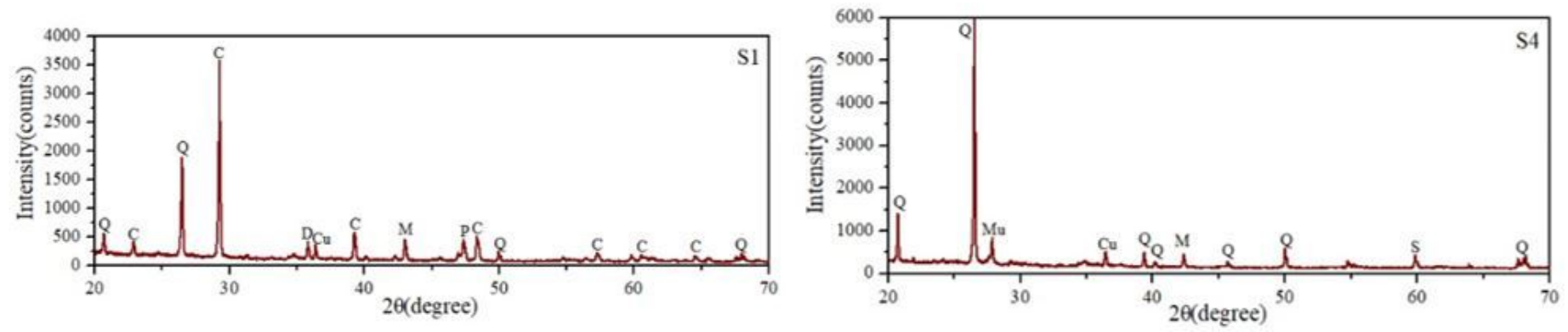
Figure 10

The X-ray diffraction patterns of stream sediment samples. C-Calcite; Cu-Cuprite; D-Delafossite; MMagnetite; Mu-Muscovite; P-Pyrite; Q-Quartz; S-Siderophyllite 